University of Chicago Law School

Chicago Unbound

Public Law and Legal Theory Working Papers

Working Papers

2012

\title{
Going Outside the Law: The Role of the State in Shaping Attitudes to Private Acts of Violence
}

Tom R. Tyler

Jonathan Jackson

Aziz Huq

Ben Bradford

Follow this and additional works at: https://chicagounbound.uchicago.edu/public_law_and_legal_theory

Part of the Law Commons

Chicago Unbound includes both works in progress and final versions of articles. Please be aware that a more recent version of this article may be available on Chicago Unbound, SSRN or elsewhere.

\section{Recommended Citation}

Tom R. Tyler, Jonathan Jackson, Aziz Huq \& Ben Bradford, "Going Outside the Law: The Role of the State in Shaping Attitudes to Private Acts of Violence" (University of Chicago Public Law \& Legal Theory Working Paper No. 372, 2012) available at http://www.

This Working Paper is brought to you for free and open access by the Working Papers at Chicago Unbound. It has been accepted for inclusion in Public Law and Legal Theory Working Papers by an authorized administrator of Chicago Unbound. For more information, please contact unbound@law.uchicago.edu. 


\title{
Monopolizing Force? \\ Police Legitimacy and Public Attitudes toward the Acceptability of Violence
}

Jonathan Jackson*, Department of Methodology and Mannheim Centre for Criminology, LSE Aziz Z. Huq, Law School, University of Chicago Ben Bradford, Centre for Criminology, University of Oxford

Tom R. Tyler, Yale Law School

\begin{abstract}
Why do people believe that violence is acceptable? In this paper we study people's normative beliefs about the acceptability of violence to achieve social control (as a substitute for the police, for self-protection and the resolution of disputes) and social change (through violent protests and acts to achieve political goals). Addressing attitudes towards violence among young men from various ethnic minority communities in London, we find that procedural justice is strongly correlated with police legitimacy, and that positive judgments about police legitimacy predicts more negative views about the use of violence. We conclude with the idea that police legitimacy has an additional, hitherto unrecognized, empirical property - by constituting the belief that the police monopolise rightful force in society, legitimacy can create a 'crowding out' effect on positive views of private violence. [131 words]
\end{abstract}

Key words: Attitudes towards violence; public trust; procedural justice; institutional legitimacy; policing

Manuscript; 9,512 words (without endnotes, references and tables)

\footnotetext{
Corresponding author: Dr Jonathan Jackson, Department of Methodology, Columbia House, LSE, Houghton Street, London WC2A 2AE, United Kingdom. Tel: +44 207 9557652. Email: j.p.jackson@1se.ac.uk
} 


\section{INTRODUCTION}

In August 2011 riots spread from London to the provincial English cities of Birmingham, Bristol, Leeds, Liverpool and Nottingham. Before the fires cooled, politicians and commentators rushed to explain not only the apparent willingness of a small number of citizens to participate in, but also a larger number willing to condone violent riots. Posited explanations ranged from social deprivation to insufficient policing to 'criminality, pure and simple' (Economist, 2011). When four British nationals detonated explosives on buses and trains in London in 2006 - killing themselves and 52 others - commentators similarly stressed the need to understand why some are willing to commit violence and why others tolerate or even approve of terrorist violence (Leiken, 2012; Pargeter, 2008).

Some varieties of violence may be socially desirable - individuals can have a need or opportunity to resort to force in self-defence or in defence of property (Getzler, 2005; Squires, 2006), especially if formal sources of social control are weak or absent (Black, 1983). Violence to change an unjust social order is sometimes desirable - and certainly impossible to extinguish entirely (Arendt, 2006). But even if private violence is occasionally unavoidable, it is still necessary to understand when and why people hold positive views of violence. Since states cannot effectively predict or target in advance the specific individuals responsible for violent conduct of the kind seen in August 2011 or July 2006 (and April 2013 at the Boston Marathon), it is advantageous for them to work instead to develop certain public predispositions against violence.

Public attitudes to violence outside formal state channels, either as a means of social control or social change (hereinafter, collectively 'private violence'), thus merit study. We examine the role of state actions and legitimacy in people's willingness to use violence outside of formal legal or institutional channels. Prior research indicates that the perceived legitimacy of the criminal justice system activates self-regulatory mechanisms: when people believe that legal authorities have the right to power and the right to dictate appropriate behaviour, they tend to defer to, and cooperate with, legitimate authorities because they feel it is the right thing to do (e.g. Tyler, 2003, 2006a, 2006b, 2011a, 2011b; Bradford et al., 2013a; Elliott et al., 2011; Huq et al., 2011a, 2011b; Jackson et al., 2012a, 2012b; Mazerolle et al., 2013; Murphy \& Cherney, 2012; Tyler, 2006a, 2006b; Tyler et al., 2010). This work also shows the centrality of procedural justice to legitimacy: when police act in line with the norms and values of procedural justice, members of the public tend to believe that the police have the right to power.

An influential body of evidence thus points to the idea that legal authorities can encourage citizens to regulate themselves when they act according to principles of procedural fairness (Sunshine \& Tyler, 2003; Tyler et al., 2010). As a contribution to the literature, we generate new empirical insights into normative beliefs about violence (to achieve certain social and political goals) among a sample of young men from various ethnic minority communities in London. To our knowledge, no study has addressed the links between public attitudes towards violence and their perceptions of the legitimacy of the police (often the most available and salient representative of the state, see Bittner, 1970). Yet a foundational aspect of liberal democracy is that the police and the justice system monopolize force and violence in society. The police are independent arbiters in times of conflict, meaning that citizens do not have to seek redress for themselves. When citizens cede the legitimate use of force to the police (and the state more generally), they explore non-violent avenues.

Prior research has defined legitimacy as the right of legal authorities to exercise power, prescribe behaviour and enforce laws (Tyler, 2006a, 2006b); the recognition and justification of police power and influence involves the belief that the police have a 'just, fair and valid basis of legal authority' (Papachristos et al., 2012: 417). Extending this definition to include the recognised right to sole use of force in society, we consider the idea that police legitimacy judgments and positive attitudes to private violence have a zero-sum relation in the aggregate. To the extent that the police gain legitimacy, they may secure a perceived normative monopoly on rightful force (Geerth \& Mills, 1946). Positive police legitimacy judgments may have a 'crowding out' effect on attitudes to private 
uses of violence. Conversely, the less legitimate the police are perceived to be, the more private violence may be tolerated, and the ends are seen to justify the means.

This paper assesses the empirical links between how the police exercise their authority (procedural justice), whether the policed recognise and justify police power, and whether those policed also believe it is acceptable to use violence to achieve certain social and political goals. To that end, we draw on survey data gathered prior to August 2011among young, male Londoners of various ethnic minority origins. This is a heavily policed subpopulation in which we expect to find significant contact with the police, and therefore significant variation in attitudes toward the police (cf. Bradford et al., 2009; Bradford \& Myhill, 2011; Jackson et al., 2012a; Skogan, 2006; Tyler \& Fagan, 2008). It is important to note, however, that we do not treat our sample as representative of the British public. Nor do we trust our sample as representative of young males from various minority ethnic groups in London. We exploit intra-sample variation to identify the correlations between contact with the police, procedural justice, legitimacy, and private violence judgments. Focusing on two forms of private violence, which we label violence as social control (i.e., as a substitute for the police) and violence for social change (i.e., as an alternative to accepted channels of political voice), we asked individuals in our sample whether they thought that it was right or wrong for a person to use violence to protect themselves from attack, to take revenge, to protest against injustice and globalisation, and so forth.

A few more caveats should be made at the threshold. First, work on procedural justice typically uses surveys to capture heterogeneity among national or city-wide probability samples. Our analytical strategy is consistent with some of the foundational studies in this area (e.g. Sunshine \& Tyler, 2003; Tyler, 2006a; Tyler \& Huo, 2002; Tyler et al., 2010). We collect observational data, we model associations between contact, trust, legitimacy and a particular potential outcome (here, attitudes towards violence), and akin to earlier procedural justice studies, our work does not provide evidence for any causal claims. But our study does slot neatly into a large body of empirical evidence on the links between procedural justice and various law-related behaviours and attitudes. Prior studies have linked legitimacy to compliance, cooperation and willingness to empower the police. We add to that list people's normative beliefs about the use of violence to achieve certain social and political goals (cf. Loeber et al., 1998).

Second, this study focuses on police legitimacy not on the legitimacy of the state as a whole. Police legitimacy warrants special study, not only because of the police's unique association with coercion (Bittner 1970; Brodeur, 2010; Loader \& Mulcahy, 2003), but also because of the frequency and density of police-citizen interactions. Third, this study addresses only two discrete types of private violence (for social control and social change). This does not exhaust the possible forms of private violence. The latter may also be motivated, for example, by familial status disputes or collective (national, ethnic, or even soccer-related) identifications (Tilly, 2003). Nor do we address potential collective dynamics in the production of private violence (Stott \& Reicher, 1998). The results are thus only a starting point in a literature that has not addressed links between procedural justice, legitimacy, and attitudes towards private violence.

Fourth, we cannot emphasize strongly enough that our study concerns expressed attitudes not actual behavior. Prior procedural studies have linked legitimacy to self-reported compliance behaviour, mostly focusing on low-level 'everyday crimes,' including 'taking inexpensive items from stores without paying' (Sunshine \& Tyler, 2003: 545), 'buying something that might be stolen' (Jackson et al., 2012a: 1064) and 'try to avoid paying as much tax as possible' (Murphy et al., 2009: 7). To our knowledge only Papachristos et al. (2012) has linked perceived police legitimacy to actual (self-reported) violent behaviour (carrying a gun and getting into a fight). We accept that attitudes to private violence will not perfectly correlate with decisions to use violence (see, e.g., Phillips, 2003). But we do believe that approval of private violence is an important object of public policy attention. Such approval is likely to be associated with behaviour, as well as the condoning of other people's behaviour. People who think it is morally acceptable to use violence to achieve certain goals may be 
more likely to engage in the act if the situation arose, less likely to condemn other people's behaviour, and less likely to assist legal authorities in the detection and prosecution of violent acts.

Fifth, the choice to sample ethnic and religious minorities reflects no implicit judgment about the distribution of propensities of violence. Rather, members of ethnic and religious minorities in London are heavily policed and have heterogeneous views of law enforcement (Macpherson, 1999; Mythen et al., 2009). Hence, the choice of sampled population indicates our effort to secure useful data by sampling a population likely to vary greatly in attitudes toward police. We consequently advance no claim about the correlations of youth, ethnicity, or faith with attitudes to private violence. It is also important to acknowledge that the survey was initially conducted on behalf of the London Metropolitan Police Service (MPS), partly in order to investigate possible negative implications arising from the adversarial relations some young Londoners from some ethnic groups have with the police (see Bradford, 2012). The MPS has a long standing interest in issues of 'trust and confidence' and public opinions of police more widely (Stanko et al., 2012), and fields a large scale, London-wide public attitudes survey on an ongoing basis. As ever, though, such surveys are likely to under sample exactly those groups most likely to have contact with officers; furthermore, at the time the present survey was fielded the MPS was particularly concerned that the 'Prevent' strand of its counterterrorism strategy, which aimed to divert people at risk from radicalization, was not reaching its intended audience. The current survey was conceived as a (necessarily partial) way of addressing both these issues.

The article has seven parts. In section two we outline past work on procedural justice and legitimacy. The third part situates our study in respect to earlier studies linking state legitimacy with attitudes to private violence. The fourth introduces a small number of alternative possible factors that may explain variation in attitudes towards private violence. The fifth explains the methodology of this study and the sixth presents the results. The seventh section discusses the implications of the results and identifying opportunities for future research. A brief conclusion suggests potential avenues of further research.

\section{THE PROCEDURAL JUSTICE FRAMEWORK}

The study employs Tyler's procedural justice model to (a) define and measure procedural justice, (b) define and measure legitimacy, (c) link procedural justice to legitimacy, and (d) link legitimacy to attitudes towards private violence. Three decades of procedural justice research have demonstrated that people are concerned with whether police decisions are made through fair procedures and whether they are treated in an interpersonally fair manner during decision-making processes - collectively 'procedural justice' (Tyler, 2006b, 2011; Tyler \& Huo, 2002). Procedural justice judgments are partly a function of the quality of immediate contact with police, and while debate persists over whether positive as well as negative encounters with police will influence judgments of the police (Bradford et al., 2009; Myhill \& Bradford, 2011; Skogan, 2006; Tyler \& Fagan, 2008), past research suggests overall that negative encounters have a large negative impact whereas positive encounters have only a moderate positive impact (Jackson et al., 2012a, 2012b).

The procedural justice model was developed to test the hypothesis that people's compliance with the law is shaped by evaluations of the quality of the conduct of criminal justice agents primarily the police - as distinct from the outcome of their decisions (Tyler, 2006a). Previous studies have found that procedural justice induces a belief in the legitimacy of police (Sunshine \& Tyler, 2003). Being treated fairly communicates value and respect within the group, which then stimulates moral identification with the collective, as well as the internalization of the value that one should obey group rules and directives. Legitimacy is here defined not only as a positive endorsement of the moral validity of police power and authority (Hough et al., 2013a, 2013b; Bradford et al., 2013b), but also as a felt positive obligation to defer to authorities such as the police (Tyler, 2006a, 2006b). Legitimacy is reflected not only in the extent to which individuals believe they have a set of duties and responsibilities in relation to the police, but also in people's judgements about the morality of police action (for ongoing debate about the meaning of legitimacy, see Bottoms \& Tankebe, 2012; 
Tankebe, 2013; Tyler \& Jackson, 2013; Hough et al, 2013b). People's feeling of obligation toward legitimate authority figures are important, in short, but so also are people's beliefs that the authority represents a set of core moral values that they themselves share.

Studies have identified three desirable downstream effects of positive legitimacy judgments. First, legitimacy seems to motivate compliance with the law (Tyler, 2006b; Jackson et al., 2012a). Second, legitimacy explains variation in voluntary public cooperation with law enforcement efforts (Tyler \& Fagan, 2008; Tyler et al., 2010). Third, legitimacy predicts people's willingness to empower the police (Sunshine \& Tyler, 2003). Demonstrations of procedural justice by police officers are also linked to reductions in the likelihood that police-citizen encounters end in violence (Mastrofski et al., 2002). And,while initial work on procedural justice was carried out in the US, Mike Hough and others have recently extended that model to the UK (Bradford et al., 2009; Hohl et al., 2010; Hough et al., 2010; Huq et al., 2011b; Jackson et al., 2012b; Bradford, 2012; European Social Survey, 2012; Hough, 2012, 2013), confirming the existence of procedural justice effects of public contact with legal authorities within the British population.

Our contribution in this paper is to examine a fourth potential outcome of legitimacy: namely, the belief that it is (morally) unacceptable to use violence to protect oneself, violence to take revenge and resolve disputes, and violence to achieve certain political objectives (e.g. to use violence in the name of religion to protest). While prior studies have linked procedural justice to legitimacy to willingness to empower the police (Sunshine \& Tyler, 2003), no study has addressed attitudes towards private violence. Yet, the nature of legitimacy invites the hypothesis that recognizing that the right to the police to dictate appropriate behaviour is also to believe that one should not use violence to achieve certain goals - that the police have a right and just monopoly over violence in society. The procedural justice model thus provides a logical starting point for exploring the influence of normative views of the state in forming individuals' attitudes toward private violence; as a mechanism of social influence, the authorization at the heart of legitimacy may extend to conferring to the police the sole right to force.

One of the few prior empirical studies to explore this question (tangentially) was in a West African context, Ghana, in which police are perceived as 'unresponsive' and 'incorrigible' such that 'sections of Ghanaian society ... have resorted to vigilantism and other forms of self-help' (Tankebe, 2009). Tankebe drew on survey data about policing and vigilantism in the Ghanaian city of Accra to test the role of state effectiveness and fairness in predicting attitudes toward nonviolent self-help (e.g. citizens beating up crime suspects, taking the law into one's own hands if one feels the police are unable to protect them, and not hanging over suspect criminals to the police). He found that judgments about the trustworthiness of the police (i.e. agreement with statements like 'I am proud of the police in Ghana', 'The Ghana police are usually honest,' and 'the Ghana police always act within the law') were negatively correlated with support for vigilantism, while judgments of police effectiveness were not a significant predictor of such support. ${ }^{i}$

Yet, because the institutional weaknesses of the Ghanaian police does not hold in the UK, it cannot be assumed that Tankebe's findings will generalize to contexts in which police are generally perceived as fair and the state as reliable. Moreover, Tankebe's study focused on vigilantism not the array of forms of private violence considered here, and he did not measure legitimacy, which is the central organizing concept in the current investigation. There is hence a need to investigate the connection between procedural justice, police legitimacy and public attitudes towards violence.

\section{STATE LEGITIMACY AND ATTITUDES TO PRIVATE VIOLENCE}

Links between normative views of the state and attitudes to private violence have also not been extensively studied outside the procedural justice literature. There is, to be sure, an enormous psychological literature concerning violence (for reviews, see Ferguson, 2010; Jones, 2000). Within the field of psychology there is extensive scholarship on topics as diverse as individual risk assessment (see, e.g., Monahan et al., 2005; Skeem \& Monahan, 2011), racial differences (see, e.g., 
Hawkins, 2003; Kubrin \& Weitzer, 2003), the relevance of firearms (see, e.g., Cao et al., 2002), local custom and practice (see, e.g., Cohen, 1996), and the effects of victimization (see, e.g., Marshall \& Webb, 1994). Outside the psychological literature the study of violence generally "focuses on either structural or cultural explanations" (Kubrin \& Weitzer, 2003). In the psychology of terrorism literature, a large body of work aims to develop individual risk assessment tools. But a recent comprehensive survey finds "little existing evidence supporting the nontrivial validity of any individual risk factors for terrorism" (Monahan, 2011). There is also a large body of non-quantitative work of variable quality concerning the aetiology of terrorism (for summaries, see Horgan, 2005; Muro-Ruiz, 2002), yet no study of the relationship of state legitimacy to violence for social change.

A handful of empirical and theoretical studies posit potential links between state legitimacy and private violence. Seminal in this regard is Black's (1983) work on 'crime as social control.' Pointing to the interaction between the state's absence and the distribution of violence, Black suggested that what the modern state categorizes as crime is often the moralistic pursuit of justice or otherwise a form of conflict resolution (see also Katz, 1988). He predicted an uneven distribution of violence as social control correlating to the varying availability of legal remedies and unresolved social grievances. Following Black, however, there has been little work on whether people's normative attitudes toward the state predict their attitudes about private violence. A few studies of criminal justice have touched upon the link. Bilz (2007), for example, postulates that crime victims' willingness to delegate vengeance to the state correlates with normative evaluations of the criminal justice system. But he conducts no empirical test of the thesis.

Studies of terrorist violence tend to focus on national-level and conflict-level predictors of terrorism (Krueger, 2007; Newman, 2006; Pape, 2005; Pape \& Feldman, 2010). Efforts to identify other individual traits that predict acts of political violence have, as noted, generally been unavailing (Kruglanski \& Fishman, 200; Monahan 2011). Nevertheless, one empirical study of patterns of extremist groups' rhetoric identifies the illegitimacy of civil government as a reiterated theme (Saucier et al., 2009). Furthermore, two empirical studies touch on the relationship between individual views of the state and political violence. But neither conclusively responds to the questions addressed here. First, Tyler and colleagues studied Muslim populations in London and New York (Huq et al., 2011b; Tyler et al., 2010). Investigating predicates of cooperation and compliance in counterterrorism policing, they found procedural justice predicted expected cooperation in counterterrorism policing in both locations. These studies used attitudes to foreign policy as a control in multivariate analysis of cooperation, but found no effect from that variable. Second, Fair and colleagues analyzed popular attitudes in Pakistan toward militancy and violence (Fair et al., 2010; Shapiro \& Fair, 2009). They identified no correlation between attitudes toward democracy and toward militancy. Importantly, neither study illuminates how police legitimacy judgments influence attitudes to private violence for social change.

In sum, neither the procedural justice literature nor other bodies of scholarship have investigated the relationship between state legitimacy and private violence at the individual level.

\section{ALTERNATIVE EXPLANATIONS}

To model associations between contact, procedural justice, legitimacy and attitudes towards violence, we fit a series of linear regression models, and we enter into the equation four further potential predictor variables, both as control variables and as potentially substantive factors.

First, we add people's assessments of police effectiveness. While studies utilising procedural justice theory tend to find that assessments of police effectiveness tend be less important predictors of legitimacy than justice judgements, this is by no means a firm conclusion. Research in contexts outside the US and UK, for example, has found that effectiveness judgements may be an important predictor of legitimacy in contexts where the social position of police is precarious (Bradford et al., 2013a; Tankebe, 2010). We might also hypothesize that people's orientations toward the potential use of violence are shaped directly by assessments of police effectiveness: when people believe police are 
effective in dealing with crime, for example, they may on instrumental grounds take the position that acts of violence are unjustified because they will elicit an effective police response; alternatively, they may feel violence is unnecessary because the police are 'in control'.

A second predictor tested in this study is fear of crime. Previous studies have found that fear of crime influences individual behaviours, such as crime avoidance, self-protection, and lifestyle adjustments (Miethe 1986; Rengifo \& Bolton, 2012). But these studies have not focused on attitudes to private violence as distinct from defensive responses to crime. Two studies offer some reason for taking the link seriously. First, Ziegenhagan and Brosnan (1991) found that fear of victimization among New York City subway riders predicted support for vigilante groups. A second study, conducted in London, identified a correlation between frequent and dysfunctional worry about crime and confidence in police (Gray et al., 2011), suggesting that people who tend to frequently worry about crime (decreasing quality-of-life rather than motivating care and precaution, see Jackson \& Kuha, 2010) have diminished confidence in, and hence be less likely to rely on, the police. As a corollary to diminished trust in police, people with heightened fear of crime may also find it more acceptable to use violence for protection. Indeed, fear of crime may even have an effect upon attitudes to private violence unmediated by attitudes toward the police or the state. That is, people who fear more for their own safety may feel more motivated to see violence as acceptable, out of an instrumental goal to protect oneself regardless of how police are viewed. Either mechanism would suggest that fear of crime will explain variation in positive attitudes to private violence.

The third predictor we consider is a feeling among young men from various minority communities that they belong to Britain. It is possible to hypothesize that national belonging will have either a negative or a positive correlation with private attitudes toward private violence. First, a sense of national identity might correlate with a belief that the criminal justice system has an exclusive right to use violence. This state's power to condemn and punish their criminal wrongdoing can be conceived in relational terms that "depend [...] on the criminal law's status as the law of a political community whose members can collectively claim such authority over each other" (Duff, 2012). Second, and alternatively, national identification might be positively correlated with positive views of private violence. It is well known that some private violence can be motivated by collective identification with the nation (Hechter, 1995, Tilly, 2004). It might further be hypothesized that increasing identification with the nation is correlated to a belief that the state shares one's normative orientation toward crime and disorder, and therefore that private violence to enforce that normative vision is a positive choice. On either hypothesis, the possible statistical effect of national identification is separate and distinct to any effect of police legitimacy.

The fourth predictor employed here are attitudes towards democracy. The correlation between attitudes to democracy - as distinct from national identification — and attitudes to private violence has been studied in other contexts, with no result being identified in one study in Pakistan (Shapiro \& Fair 2009). But is it possible to hypothesize that the existence of a generally democratic mechanism for the resolution of social disputes will have a (likely negative) correlation with attitudes to public violence. Because this hypothesized mechanism focuses specifically on the perceived availability of a political process that obviates the use of violence by private citizens, it is conceptually separate from national identification effects. We include this predictor because our sample may include a high proportion of individuals with experience of nondemocratic contexts.

\section{RESEARCH QUESTIONS AND METHODS}

\section{A. STUDY SETTING AND METHODOLOGY}

Our study is set in London. This is a suitable locus for the current investigation because it has recent experience with crime, political violence, and social unrest; both knife and gun crime are perceived as serious problems by the public (Miller, 2010); there is significant fear of crime among residents (Gray et al., 2011); and after the terrorist attack of July 2005 there have been numerous arrests in London connected to terrorism prosecutions (Pargeter, 2008). Domestic-source terrorism is 
also seen as a long-term problem among majority and minority communities (Lum et al., 2009), and police and ethnic minorities in London have long had a difficult relationship plagued by concerns of structural racism in the Metropolitan Police (Macpherson, 1999). Counterterrorism policing after 2001 may have conducted with a greater concentration of law enforcement resources on ethnic minorities perceived as Muslim (cf. Mythen et al., 2009; Greer, 2010).

Data for this study are drawn from a sample of 1,017 respondents drawn in 2010 from four of London's thirty-two subunits of municipal governance (called London Boroughs ${ }^{\mathrm{ii}}$ ). The sample was a supplement to a larger public attitudes survey conducted on a rolling basis by the Metropolitan Police Service (cf. Stanko et al., 2012). The current special population survey addressed only young (sixteen to thirty years of age) male respondents self-identifying as members of a non-majority ethnic or racial group, with respondents asked questions drawn from previous studies of policing and legitimacy (Tyler \& Huo, 2002; Sunshine \& Tyler, 2003; Tyler, 2006a) and UK (Fitzgerald et al., 2002; Bradford et al., 2009; Jackson et al., 2012a, 2012b). Hence, we focus on this population because it has traditionally had more contact and more antagonistic relations with police. We expect to find greater variance in attitudes towards violence in comparison to the general population. But because we analyze only intrasample variance, we do not estimate any relationships concerning shared characteristic of the particular sample, including minority racial status, gender, and youth. We also offer no inferences about the general population of the other London boroughs (or London as a whole).

The sampling process was as follows. Approximately 250 interviews were carried in each of four London boroughs with high concentrations of ethnic and racial minority populations (Hounslow, Newham, Southwark and Tower Hamlets), yielding a total of 1017 interviews. The first stage of sample design involved selecting wards within each borough. Five wards were randomly selected from each borough, with the probability of selection proportionate to a Census-based estimate of the number of eligible respondents in the ward (i.e., wards with a higher concentration of individuals from various ethnic minority communities were more likely to be selected). Second, and again within each selected ward, there was random probability selection of five Census Output Areas (OAs) weighted according to number of eligible respondents in each OA. Third, for each selected OA, all OAs adjoining or near to it were identified; four were then randomly selected. This gave a total of five sampling points, each comprising five 'clustered' OAs. Finally, the interviewer team was provided with all the addresses in the selected sample point (from PAF) and instructed interviewers to free-find ten eligible respondents and to conduct in-person interviews at their homes. A total of 25 sampling points (ten interviews in each) were issued for each borough giving 100 sample points in all. Inperson interviews were conducted in 2009.

One noteworthy disadvantage of this quota-based sampling approach is the likelihood of bias related to interviewee characteristics (e.g., people likely to be more available to the interview team during the evening and people afraid of answering their door to strangers may tend to be underrepresented). This creates a risk of either underreporting or over-reporting certain subpopulations. However, these kinds of bias are difficult to eliminate by explicit weighting factors. Indeed, the stricture also applies to the random address method, absent repeated attempts to re-contact non-replying addresses. There is, moreover, a further possibility that some respondents' answers are shaped by social desirability, in that they present themselves in a positive light to interviewers.

\section{B. DEMOGRAPHIC CHARACTERISTICS}

All respondents were aged between 16 and 30. There wasan even distribution within that range, with somewhere between 56 and 83 people (between 5\% and $8 \%$ ) being of each specific age (mean of 23 years old, standard deviation of 4.5). Just under half of the sample classified themselves as 'Indian' (22\%) or 'Bangladeshi' (26\%), with a further fifth of the sample classifying themselves as 'Black African' (19\%). The sample contained significant religious diversity. Of 928 respondents who self-reported a religious identity, 454 (49\%) identified as Muslim, 249 (27\%) as Christian, 129 (14\%) 
as Hindu, $38(4 \%)$ as Jewish, $32(3 \%)$ as Sikh, and $21(2 \%)$ as Buddhist. Two respondents identified as Rastafarian and one as Shinto.

On economic status, $34 \%$ of the sample reported being in full time (30+ hours per week) employment, $12 \%$ as part-time (8-29 hours per week), $44 \%$ were students, and $8 \%$ were either not working or full-time unemployed. Respondents were also categorized according to the self-identified employment of the chief income earner in the household as social class A (0.2\%), B (8\%), C1 (43\%), C2 (18\%), E (17\%) and E (14\%). ${ }^{\text {iii }}$

\section{OUTCOME AND PREDICTOR VARIABLES}

The appendix details the survey questions used to construct the predictor and outcome variables, as well as the means, standard deviations and range of the relevant scales.

Three outcome variables were specified in the current study. First, respondents were asked two questions about the use of violence as self-protection. Answers to these questions were used to construct a scale entitled 'protect' (the mean was taken). Second, respondents were asked two questions about the use of violence in interpersonal disputes. Answers to which were used to construct a scale entitled 'dispute' (the mean was taken). These protect and dispute variables measure respondents' normative attitudes to private violence as social control. But they focus on two distinct social-control functions. Third, respondents were asked for their view of violence as political protest against unfair public policies, against globalization, or on religious grounds. Responses to the four questions were scaled into a single variable called 'political violence' using latent trait analysis, implementing full information maximum likelihood to reduce the impact of item non-response.

In the construction of each of these variables, we drew no distinction between attitudes to violence for expressive ends or for instrumental ends. We hypothesize that most respondents have not developed distinct attitudes to the same act of violence when it is committed to express a viewpoint and when it is an instrumental means to an end. Accordingly, the present study does not address the question whether instrumental and expressive forms of violence elicit different attitudes.

Note, also, that respondents were asked only whether each kind of violence was right under specified circumstances. They were not asked whether or when violent self-help is legal. Nor were they asked whether they were likely to use such violence themselves. These measures thus capture normative attitudes toward violence, and are not evidence of proclivities to use violence. We further note that information elicited about the expected use of violence may be less reliable than information about normative attitudes, since respondents may have more cause to underestimate their proclivity for violence than to distort expressions of normative judgments.

Seven clusters of predictor variables are examined. First, respondents were asked whether they had been stopped by the police or searched and/or arrested by the police in the past 12 months; those who had had such contact were also asked whether the officer(s) treated them in a procedurally fair manner during the encounter. Were they given a reason for being stopped? Were they told what was going to happen next? Were they treated with respect? Was the police justified in stopping them? We created three variables corresponding to whether someone had (a) been stopped and felt that they experienced no procedural justice from the officer(s) in question, (b) been stopped and felt that they experienced some procedural justice from the officer(s) in question, or (c) been stopped and felt that they had experienced procedural justice from the officer(s) in question. We outline the procedure for this in the appendix.

Second, respondents were asked about their trust in the procedural justice of the police ('procedural justice'). This variable captures judgments about the way in which police officers wield their power, without focusing respondents' attention on specific recent encounters (again, see appendix). It is important to measure both prior contact (particularly whether the young men thought they were treated fairly) and judgments of the trustworthiness of the police to be procedurally fair. 
Not all the respondents will have had a bad contact with the police, but people still hold assumptions about how the police generally wield their power, and about how they would be treated if they were to come into contact with officers. ${ }^{\text {iv }}$

Third, respondents were asked about views relating to the legitimacy of the police ('legitimacy'). This scale relies on questions developed in the larger procedural justice literature to measure the recognition and justification of police power (Tyler, 2006a, 2006b, 2011). In particular, our measures draw on notions of felt obligation, moral alignment and perceived legality (Hough et al., 2010, 2013a, 2013b; Jackson et al., 2011, 2012a, 2012b). Of note is the fact that we deviate slightly from Tyler's approach of combining trust/confidence and felt obligation measures into one index of legitimacy (see also Goff et al., 2013), as well as Gau et al.'s (2012) approach of using just trust/confidence measures to indicate legitimacy. We also depart from Tankebe's (2013) approach, which operationalizes legitimacy as people's perceptions of the effectiveness, fairness and lawfulness of the police. ${ }^{\mathrm{v}}$ Our approach is more similar to that of Papachristos et al. (2012: 417), who defines perceived legitimacy as the "extent to which an individual states that he or she believes that the law (or legal agents) represents a just, fair, and valid basis of legal authority,' measuring felt obligation to obey and perceptions of the validity of police power. ${ }^{\text {vi }}$

The remaining four predictor variables address alternative explanations for attitudes to violence (see appendix). The fourth predictor variable concerns trust in the effectiveness of the police ('effectiveness'). This is a means to determine whether instrumental judgments about the police influence attitudes toward private violence. The fifth measures respondents' views about the desirability of democracy as a mode of governance ('pro-democracy'). This is a means of gauging normative attitudes toward the current British political system, without relying upon partisan affiliations. The sixth measured a respondent's level of worry about being victimized ('fear of crime'). ${ }^{\text {vii }}$ The seventh gauged their identification with the British nation ('belonging'). The survey instrument also gathered basic demographic information: age, social class, work status, housing status, and self-reported ethnic and racial identification.

Correlations between key predictor variables are provided in Table 1. Briefly, we find moderately strong (bivariate) associations between trust in police procedural justice, trust in police effectiveness and perceptions of the legitimacy of the police.

As a first step, confirmatory factor analysis (using MPlus) was used to assess the dimensionality of the measures of attitudes towards violence and police legitimacy. We used confirmatory factor analysis because we had a priori expectations about the dimensionality of the variables. To assess the empirical distinctiveness of attitudes towards violence and police legitimacy, a four-factor model was tested. The fit was reasonable according to the approximate fit statistics $\left(\chi^{2}\right.$ $=371, d f=59, p<.001 ;$ CFI=.93; RMSEA=.07, 90\% CI .06-.08). Recognising and justifying police power seems to be empirically distinct to accepting the use of violence to achieve certain goals. The three different types of violence attitudes also seem to be distinct. The factor loadings of the indicators of attitudes towards violence and police legitimacy were all statistically significant and of considerable magnitude.

\section{[Insert Table 1 about here]}

\section{RESULTS}

This study examines relationships between attitudes toward private violence, instrumental judgments about police effectiveness and normative views of the police informed by contact with officers. For each of the three outcome variables - protect, dispute and political violence-we fit a series of linear models. First, we test a model that examines the effect of encounters with the police. Second, we test a model that includes one normative motivation (procedural justice) and beliefs about the effectiveness of the police. Third, we add a further normative motivation (legitimacy). Fourth, we add the final set of predictor variables: pro-democracy, fear of crime, and belonging, which may 
provide alternative explanations to the instrumental and legitimacy variables that are the principal focus of the study. This stepwise approach allows precise identification of the separate effects of instrumental and normative judgments respecting the police on the outcome variables of interest. Separate treatment of procedural justice and legitimacy elucidates whether the former has separate effects from legitimacy judgments, as has been found in past studies. Moreover, separate treatment of contact and procedural justice perceptions enables more precise determination of the bases of normative judgments about the police. The particular nature of the hierarchical modelling reflects the procedural justice framework, which predicts that contact explains variation in trust, which then explains variation in legitimacy.

Tables 2-4 report the results of the fitted linear models, with protect, dispute, and political violence (respectively) as outcome variables. Note that working status, housing status, and social class variables are reported in disaggregated form. Note also that the size of the sample in these regressions has dropped from 1,017 to 836,842 and 868 (depending on the outcome variable) because respondents with missing variables for any of the questions relevant to the analysis have been dropped from the fitted models. The majority of the missing values came from dispute (42 missing values), protect (45 missing values), political violence (15 missing values), social class (46 missing values), home status (22 missing values) and attitudes towards democracy (42 missing values). Of note is that the models were estimated without social class with no effects on the results.

\section{[Insert Tables 2-4 here]}

The fully specified models for the protect, dispute, and political violence outcome variables explained respectively $15 \%, 13 \%$ and $16 \%$ of observed variance. The relatively low amount of explained variance suggests the need for further research to uncover factors explaining further variation. Nevertheless, we do not place too much importance on $\mathrm{R}^{2}$ values, since much of the variability in people's attitudes may not be systematically explainable (being due instead to stochastic processes).

The principal results are as follows. First, we find evidence of correlation between procedural justice judgments, police legitimacy judgments, and attitudes to private violence. The study's core finding is that procedural justice explains variation in police legitimacy, which in turn is negatively correlated with attitudes to private violence. This finding can be decomposed into component parts. To begin, for all three outcome variables we find that procedural justice has a strong negative correlation with attitudes to violence when it is added in Model II. Nevertheless, this correlation diminishes or disappears when legitimacy is added to the specification for all three outcome variables (Model III). Consistent with earlier studies on the relationship between procedural justice and compliance, this implies that procedural justice has an indirect effect on attitudes to private violence via police legitimacy (Tyler, 2006a, 2006b). Procedural justice and legitimacy judgments are powerfully correlated, and the effects of procedural justice tend to be mediated by legitimacy. Moreover, in full regressions of all three outcome variables (Model IV in Tables 2-4), we find that legitimacy judgments have a strongly significant ( $p<0.01$ in two cases and $p<0.001$ in the other case) and negative relationship with attitudes to violence. This suggests that the more the police induce belief in their legitimacy - via compliance with standards of procedural justice - the less favourable are people's views about the acceptability of private violence.

Second, in Model I of each of the three sets of fitted linear models, negatively perceived contact with the police (i.e., contact without procedural justice) is a significant negative predictor of attitudes towards private violence. Importantly, this effect weakens when other predictors, most importantly procedural justice, are added to the regression. This finding suggests that negatively - but not positively - perceived contact with police is weakly correlated with an increase in positive views of private violence, and that the effect is mediated by trust in police procedural fairness and the perceived legitimacy of the police. The extent of asymmetry echoes that found by Skogan (2006). ${ }^{\text {viii }}$ 
Third, we find little evidence of correlation between judgments of police effectiveness and normative attitudes to private violence for social control. Neither of the two full regression specifications containing all independent variables explain variation in violence for social control identifies any negative conditional correlation between effectiveness judgments and normative attitudes toward any form of private violence. In the case of violence for social change, however, the full specification model finds a significant $(p<0.01)$ positive conditional correlation between effectiveness judgments and attitudes to private violence. This coefficient obtains significance, however, only when procedural justice and legitimacy were included in the model. That is, conditional on assessments of procedural justice and legitimacy, respondents who viewed the police as more effective were more likely to endorse violence for politically-related ends.

Finally, the additional predictor variables added in Model IV (fear of crime, pro-democracy, and belonging) have statistical effect in some, but not all, attitudes toward private violence. Respecting protect and dispute, these predictor variables have little statistical effect. Fear of crime alone is positively correlated with protect, which suggests unsurprisingly greater concern about the personal threat of crime correlates with more positive attitudes toward defence of self or property. The three additional predictor variables also have independent effects on attitudes toward more political forms of violence. A positive view of democracy and feelings of belonging to the nation are negatively correlated with approval of political violence. By contrast, fear of falling victim is positively correlated with the approval of political violence. That is, the state's failure to supply public safety may dampen disapproval of violence directed against the state.

\section{DISCUSSION}

This study has examined public attitudes toward the use of violence to achieve social control and social change. Addressing young males from certain minority ethnic groups in London, we have assessed whether the actions of police - specifically compliance with standards of procedural justice that then legitimize them in the eyes of the policed - correlated with people's attitudes to private violence. While our use of regression models and observational data does not permit causal inference, other studies of procedural justice effect have found that perceptions of procedural justice and legitimacy judgments are anterior to attitudes concerning cooperation with the police, self-reported compliance with the law, and willingness to empower the police (e.g. Sunshine \& Tyler, 2003; Jackson et al., 2012a; Papachristos et al., 2012). To this literature we add a fourth potential outcome: namely, attitudes towards the morality of violence action to achieve certain goals. Correlational (descriptive) findings of the kind presented here are, accordingly, a threshold step to identifying causal mechanisms.

The study's primary finding was that judgments about police legitimacy were negatively correlated with individual attitudes toward private violence for social control and social change. Consistent with a large body of research (for a review, see Tyler et al., 2013), we also found that procedural justice was strongly correlated with judgments of police legitimacy. Indeed the statistical effect of procedural justice on attitudes to private violence diminished when police legitimacy was added as a predictor variable. These results support the idea that normative judgments about the police - the most important and available vehicle of state coercion - are related not only to legal compliance and cooperation decisions, but also to attitudes to private violence. When one believes that the police have the right to power and the right to expect obedience and support, one also tends to believe that it is wrong to use violence to achieve certain social and political goals. We thus extend the definition of (perceived) police legitimacy to include not just the right to power and dictate appropriate behaviour, but also the right of the police (as the most high-profile representative of the criminal justice system) to sole use of force in society.

Contributing to previous scholarship, we have presented evidence that this connection obtains even outside of contexts in which the state systematically fails to provide public order, encompassing not only judgments about vigilantism - private action as an immediate substitute for policing - but also judgments about other forms of private violence, including politically motivated acts. Police 
legitimacy relates not just to public recognition and justification of power, but also public recognition of the state's monopoly over acceptable force. Importantly, the association between police legitimacy and attitudes to violence persisted even after controlling for trust in police effectiveness and fear of crime, which approximate respondents' views on the effective supply and demand for policing (at least instrumentally) respectively. The effect was also found with each form of private violence studied.

We have thus provided evidence that the two-stage procedural justice framework - developed initially to examine compliance and cooperation behaviour - has broader application than previous recognized. While political theorists have recognized the salience of empirical legitimacy to regime stability (Gilley, 2009), to our knowledge the significance of legitimacy judgments to attitudes toward private violence has not been examined. We emphasize that this is not the sole determinant of attitudes to private violence. The predictor variables used explained between $13 \%$ and $16 \%$ of the outcome variable. But the linkage between police legitimacy and attitudes to private violence suggests that the legitimacy of the police - the state's violence 'specialist' (North et al., 2009) - has a 'crowding out' effect on positive judgments about private violence.

Weber famously defined the legitimate state as the possessor of a monopoly on the use of violence. This study suggests that, to the extent that the state is viewed as legitimate, private violence is viewed negatively. But when the police fail to act in accordance with principles of procedural justice, legitimacy declines to the extent that it no longer crowds out more positive attitudes to private violence. There may thus be something of a zero-sum relationship between approval of state violence and approval of non-state violence. We emphasize, however, that this is not evidence that legitimacy is a causal factor relevant to explaining attitudes towards private violence. At minimum, it suggests the value of further investigation into police legitimacy's relation to public approval of private violence.

A secondary finding concerns the asymmetrical effect of police contact on legitimacy judgments. Negatively perceived, but not positively perceived, contact was associated with diminished legitimacy judgments. At least within a heavily-policed population with historically antagonistic relations with the police, it is possible that confirmations of negative priors about the police have a more pronounced effect than positive experiences. Moreover, belief in the effectiveness of the police did not have a strong and clear influence on attitudes about violence for social control. Our data are consistent with previous evidence that public compliance with the law and cooperation with police have weaker links to instrumental judgments than to procedural justice (Tyler 2006b), at least when the state functions moderately well (Bradford et al., 2013a). It is possible that effectiveness judgments could influence legitimacy, thereby indirectly influencing normative judgments about violence. But we did not find evidence of any such indirect relationship in this study of young males from various BME communities in London. ${ }^{\text {ix }}$

\section{CONCLUSION}

This study has explored the association between police legitimacy and a range of attitudes to private violence in the context of a generally functional and broadly accepted state. Working within the framework of procedural justice, we have identified a significant negative correlation between normative judgments about the police and public attitudes to diverse kinds of private violence. We hope that this finding opens up a new line of thinking about the aetiology of private and informal forms of violence, in which policy-makers are more open to self-reflection and an examination of not merely others inherent 'criminality,' but also the effects of the state's own policy decisions.

We should, however, return to two of the caveats we set earlier in the paper. First, because we have not experimentally manipulated procedural justice and legitimacy, we cannot infer direct and indirect causal effects from our data. We have found robust associations in a special population - i.e. young males from various minority communities in London. But more randomized controlled trials are needed if the body of evidence is to become truly persuasive (e.g. Mazerolle et al., 2013). We recommend future experimental work to examine numerous potential outcomes of legitimacy, 
including normative beliefs about violence as a means to achieve certain ends. Second, we have measured attitudes towards violence as a means of self-protection, a means of resolving disputes, and a means of achieve political goals, not actual violence. Of course, attitudes to private violence are not perfectly correlated with actual violence. Nevertheless, approval of private violence is an important object of public policy attention, in part because such approval is likely to be associated with behaviour and condoning of other people's behaviour. People who think it is morally acceptable to use violence to achieve certain goals may be more likely to engage in the act if the situation arose, less likely to condemn other people's behaviour, and less likely to report the event to legal authorities. A social climate of tolerance towards violence may thus emerge, with deleterious implications for social order and justice (see, e.g. Anderson, 1999). A climate that condones or supports violence has weak normative barriers to the use of force.

With these observations made, we close with a call for further research to explore the possibility that individual attitudes toward violence are shaped by the larger institutional context, specifically whether it is experienced as fair and justified. This institutional context is a concrete presence in their lives, in terms of people's contact with police officers and their wider experience of policing. Police and wider governmental policies aimed at preventing violent disorder (and indeed acts of terrorism) should attend to the quality of policing as well as its quantity (Tyler et al., 2010; Huq et al., 2011a, 2011b; Schulhofer et al., 2011). Repressive tactics, if experienced as unfair, may weaken individual's belief that it is wrong to use violence, and may yield counterproductive long-run effects. A legitimate police force is, by its very nature, representative of the state's monopoly on the legitimate use of violence. Members of the community who see the police as legitimate are unlikely to consider violence if they want to achieve social change or solve issues that confront them. They cede the legitimate use of force to the police (and the state more generally) and they explore non-violent avenues. By contrast, illegitimate and procedurally unjust policing opens up the space for citizens to use private or extralegal force to achieve certain goals. These goals could be about revenge and dispute, but they could also be about achieving social change and protesting against certain situations, arrangements and practices.

In the context of the initial disturbance in Tottenham and the spread of social unrest to areas beyond it in London in 2011, a challenge to police legitimacy initially created by unfair policing may have generated further challenges as the police appeared unable to exert their authority in a meaningful way. The appropriate policing response may not involve a shift to more aggressive or punitive styles, but to develop a more consensual way of policing inner-city areas that seeks to generate and maintain police legitimacy. This should not be limited merely to issues of fairness. Rather, the focus should be on modes of policing that encourage officers to wield their authority in such a way as to promote the sense among those encountered that they are valid holders of the monopoly of force. A key factor in this endeavour, although by no means the only one, will be developing policing styles that seek to include and involve all individuals as members of society with an active stake in the reproduction of social order. These styles are likely to relate strongly to the generation of mutual trust and a sense of shared aims; if nothing else, the social unrest in England in August 2011 has thrown into sharp relief the potential consequences of a breakdown in the relationship between police and particular publics. 
TABLES

Table 1. Zero order correlations between key predictor variables

\begin{tabular}{|c|c|c|c|c|c|c|}
\hline & $\begin{array}{l}\text { Trust in the } \\
\text { procedural } \\
\text { fairness of the } \\
\text { police }\end{array}$ & $\begin{array}{l}\text { Trust in the } \\
\text { effectiveness } \\
\text { of the police }\end{array}$ & $\begin{array}{l}\text { Perceptions } \\
\text { of the } \\
\text { legitimacy of } \\
\text { the police }\end{array}$ & Fear of crime & $\begin{array}{c}\text { Feelings of } \\
\text { belonging to } \\
\text { Britain }\end{array}$ & $\begin{array}{c}\text { Attitudes } \\
\text { towards } \\
\text { democracy }\end{array}$ \\
\hline $\begin{array}{l}\text { Trust in the procedural } \\
\text { fairness of the police }\end{array}$ & 1 & & & & & \\
\hline $\begin{array}{l}\text { Trust in the effectiveness } \\
\text { of the police }\end{array}$ & $.44 * * *$ & 1 & 1 & & & \\
\hline $\begin{array}{l}\text { Perceptions of the } \\
\text { legitimacy of the police }\end{array}$ & $.68 * * *$ & $.40 * * *$ & 1 & & & \\
\hline Fear of crime & $-.11 * * *$ & $-.22 * * *$ & -.02 & 1 & & \\
\hline $\begin{array}{l}\text { Feelings of belonging to } \\
\text { Britain }\end{array}$ & $.28 * * *$ & $.21 * * *$ & $.24 * * *$ & -.09 & 1 & \\
\hline $\begin{array}{l}\text { Attitudes towards } \\
\text { democracy }\end{array}$ & $.35 * * *$ & $.24 * * *$ & $.33 * * *$ & -.04 & $.14 * * *$ & 1 \\
\hline
\end{tabular}

$*$ correlation is significant at $5 \%$ level, $* *$ correlation is significant at $1 \%$ level, *** correlation is significant at .1\% level. 
Table 2. Fitted Linear Models of Believing that it is Acceptable to Use Violence to Protect Oneself

\begin{tabular}{|c|c|c|c|c|c|c|c|c|}
\hline & \multicolumn{2}{|c|}{ Model I } & \multicolumn{2}{|c|}{ Model II } & \multicolumn{2}{|c|}{ Model III } & \multicolumn{2}{|c|}{ Model IV } \\
\hline & $\begin{array}{c}\text { coeff. } \\
\text { (se.) }\end{array}$ & ci. & $\begin{array}{c}\text { coeff. } \\
\text { (se.) }\end{array}$ & ci. & $\begin{array}{c}\text { coeff. } \\
\text { (se.) }\end{array}$ & ci. & $\begin{array}{l}\text { coeff. } \\
\text { (se.) }\end{array}$ & ci. \\
\hline $\begin{array}{l}\text { Work status (referent: full-time, } 30+ \\
\text { hours per week) }\end{array}$ & & & & & & & & \\
\hline Part-time, 8-29 hours per week & $\begin{array}{c}0.00 \\
(0.12)\end{array}$ & {$[-0.24,0.25]$} & $\begin{array}{c}0.02 \\
(0.12)\end{array}$ & {$[-0.21,0.26]$} & $\begin{array}{c}0.03 \\
(0.12)\end{array}$ & {$[-0.20,0.27]$} & $\begin{array}{c}0.02 \\
(0.12)\end{array}$ & {$[-0.21,0.26]$} \\
\hline Not working & $\begin{array}{c}0.15 \\
(0.19)\end{array}$ & {$[-0.22,0.53]$} & $\begin{array}{c}0.22 \\
(0.19)\end{array}$ & {$[-0.15,0.58]$} & $\begin{array}{c}0.20 \\
(0.19)\end{array}$ & {$[-0.16,0.57]$} & $\begin{array}{c}0.20 \\
(0.18)\end{array}$ & {$[-0.16,0.56]$} \\
\hline Registered unemployed & $\begin{array}{l}-0.10 \\
(0.21)\end{array}$ & {$[-0.51,0.31]$} & $\begin{array}{l}-0.07 \\
(0.21)\end{array}$ & {$[-0.48,0.33]$} & $\begin{array}{l}-0.05 \\
(0.20)\end{array}$ & {$[-0.45,0.35]$} & $\begin{array}{l}-0.03 \\
(0.20)\end{array}$ & {$[-0.43,0.36]$} \\
\hline Unemployed but not registered & $\begin{array}{l}-1.08^{*} \\
(0.44)\end{array}$ & {$[-1.95,-0.21]$} & $\begin{array}{r}-0.89^{*} \\
(0.44)\end{array}$ & {$[-1.74,-0.03]$} & $\begin{array}{l}-0.82 \\
(0.43)\end{array}$ & {$[-1.67,0.04]$} & $\begin{array}{l}-0.81 \\
(0.43)\end{array}$ & {$[-1.65,0.04]$} \\
\hline Student/full-time education & $\begin{array}{l}-0.24 * \\
(0.11)\end{array}$ & {$[-0.45,-0.03]$} & $\begin{array}{l}-0.18 \\
(0.11)\end{array}$ & {$[-0.39,0.02]$} & $\begin{array}{l}-0.17 \\
(0.10)\end{array}$ & {$[-0.37,0.04]$} & $\begin{array}{l}-0.18 \\
(0.10)\end{array}$ & {$[-0.38,0.02]$} \\
\hline 'Other' employment status & $\begin{array}{l}-0.65 \\
(0.42)\end{array}$ & {$[-1.47,0.17]$} & $\begin{array}{l}-0.58 \\
(0.41)\end{array}$ & {$[-1.39,0.23]$} & $\begin{array}{l}-0.64 \\
(0.41)\end{array}$ & {$[-1.44,0.16]$} & $\begin{array}{l}-0.71 \\
(0.40)\end{array}$ & {$[-1.51,0.08]$} \\
\hline $\begin{array}{l}\text { Home/residential status (referent: own } \\
\text { home outright) }\end{array}$ & & & & & & & & \\
\hline Buying on a mortgage & $\begin{array}{c}0.06 \\
(0.17)\end{array}$ & {$[-0.27,0.38]$} & $\begin{array}{c}0.03 \\
(0.16)\end{array}$ & {$[-0.29,0.35]$} & $\begin{array}{c}0.02 \\
(0.16)\end{array}$ & {$[-0.30,0.34]$} & $\begin{array}{l}-0.02 \\
(0.16)\end{array}$ & {$[-0.33,0.30]$} \\
\hline Renting from the council & $\begin{array}{c}0.03 \\
(0.15)\end{array}$ & {$[-0.27,0.34]$} & $\begin{array}{c}0.02 \\
(0.15)\end{array}$ & {$[-0.28,0.31]$} & $\begin{array}{c}0.00 \\
(0.15)\end{array}$ & {$[-0.30,0.29]$} & $\begin{array}{c}0.01 \\
(0.15)\end{array}$ & {$[-0.28,0.30]$} \\
\hline Renting from a housing association & $\begin{array}{l}-0.08 \\
(0.20)\end{array}$ & {$[-0.47,0.31]$} & $\begin{array}{l}-0.07 \\
(0.19)\end{array}$ & {$[-0.46,0.31]$} & $\begin{array}{l}-0.04 \\
(0.19)\end{array}$ & {$[-0.42,0.34]$} & $\begin{array}{l}-0.05 \\
(0.19)\end{array}$ & {$[-0.43,0.32]$} \\
\hline Renting from a private landlord & $\begin{array}{l}-0.27 \\
(0.15)\end{array}$ & {$[-0.57,0.04]$} & $\begin{array}{l}-0.15 \\
(0.15)\end{array}$ & {$[-0.45,0.15]$} & $\begin{array}{l}-0.12 \\
(0.15)\end{array}$ & {$[-0.42,0.17]$} & $\begin{array}{l}-0.11 \\
(0.15)\end{array}$ & {$[-0.40,0.18]$} \\
\hline 'Other' home/residential status & $\begin{array}{l}-0.24 \\
(0.30)\end{array}$ & {$[-0.84,0.35]$} & $\begin{array}{l}-0.18 \\
(0.30)\end{array}$ & {$[-0.77,0.40]$} & $\begin{array}{l}-0.13 \\
(0.30)\end{array}$ & {$[-0.71,0.45]$} & $\begin{array}{l}-0.13 \\
(0.29)\end{array}$ & {$[-0.71,0.44]$} \\
\hline Social class (referent: A) & & & & & & & & \\
\hline $\mathrm{B}$ & $\begin{array}{l}-0.83 \\
(0.77)\end{array}$ & {$[-2.34,0.68]$} & $\begin{array}{l}-0.83 \\
(0.75)\end{array}$ & {$[-2.31,0.65]$} & $\begin{array}{l}-0.84 \\
(0.75)\end{array}$ & {$[-2.31,0.63]$} & $\begin{array}{l}-0.63 \\
(0.75)\end{array}$ & {$[-2.09,0.83]$} \\
\hline $\mathrm{C} 1$ & $\begin{array}{l}-0.82 \\
(0.76)\end{array}$ & {$[-2.31,0.68]$} & $\begin{array}{l}-0.76 \\
(0.75)\end{array}$ & {$[-2.23,0.70]$} & $\begin{array}{l}-0.76 \\
(0.74)\end{array}$ & {$[-2.21,0.69]$} & $\begin{array}{l}-0.54 \\
(0.74)\end{array}$ & {$[-1.99,0.91]$} \\
\hline $\mathrm{C} 2$ & $\begin{array}{l}-0.82 \\
(0.76)\end{array}$ & {$[-2.31,0.68]$} & $\begin{array}{l}-0.76 \\
(0.75)\end{array}$ & {$[-2.23,0.71]$} & $\begin{array}{l}-0.75 \\
(0.74)\end{array}$ & {$[-2.20,0.71]$} & $\begin{array}{l}-0.53 \\
(0.74)\end{array}$ & {$[-1.98,0.92]$} \\
\hline $\mathrm{D}$ & $\begin{array}{l}-0.82 \\
(0.76)\end{array}$ & {$[-2.32,0.67]$} & $\begin{array}{l}-0.77 \\
(0.75)\end{array}$ & {$[-2.23,0.70]$} & $\begin{array}{l}-0.78 \\
(0.74)\end{array}$ & {$[-2.24,0.68]$} & $\begin{array}{l}-0.60 \\
(0.74)\end{array}$ & {$[-2.05,0.85]$} \\
\hline $\mathrm{E}$ & -0.76 & {$[-2.27,0.74]$} & $\begin{array}{c}-0.76 \\
16\end{array}$ & {$[-2.24,0.71]$} & -0.76 & {$[-2.22,0.71]$} & -0.56 & {$[-2.02,0.90]$} \\
\hline
\end{tabular}




\begin{tabular}{|c|c|c|c|c|c|c|}
\hline$(0.77)$ & & $(0.75)$ & & $(0.75)$ & & $(0.74)$ \\
\hline-0.02 & & -0.02 & & -0.01 & & -0.02 \\
\hline
\end{tabular}

Stopped by the police (referent: not stopped)

....and received no procedural justice

... and received some procedural justice

(0.14)

0.01

(0.14)

....and received strong procedural

0.05

justice

$(0.15)$

$[0.24,0.79]$
$[-0.27,0.29]$
$[-0.24,0.33]$

Trust in police procedural justice

(0.14)

$-0.10$

$(0.14)$

$-0.01$

$[0.00,0.57]$

0.27

(0.14)

$-0.12$

$[-0.37,0.18]$

(0.14)

$(0.14) \quad[-0.29,0.28]$

$(0.14)$

$(0.02)$

$(0.02)$
-0.03

$[-0.14,-0.06]$

$(0.02)$

$[-0.08,0.01]$

(0.02)

$-0.02$

$(0.02)$

$-0.10 * * *$

(0.03)

0.26

Perceived police legitimacy

$[-0.01,0.55] \quad(0.14)$

$[-0.02,0.54]$

$-0.07$

$[-0.39,0.16]$

(0.14)

$[-0.34,0.20]$

Fear of crime

Feeling of belonging to Britain

Attitudes towards democracy

(Constant)

$$
5.15 * * *
$$
$(0.80)$ $[3.58,6.71]$

836
0.07

$[-0.27,0.29]$

(0.14) $\quad[-0.26,0.29]$

$[-0.10,0.00] \quad(0.03) \quad[-0.08,0.02]$

$[-0.07,0.02] \quad(0.02)$

$(0.02) \quad[-0.04,0.05]$

$-0.10 * * *$

$[-0.15,-0.05]$

(0.03)

$0.07 * * *$

(0.02) [0.03, 0.10]

$-0.02$

$(0.02) \quad[-0.05,0.02]$

$-0.03$

(0.02) $\quad[-0.07,0.01]$

$\mathrm{N}$

R-squared

$5.66 * * *$

$[4.12,7.21]$

Note: coeff $=$ unstandardized coefficient. $\mathrm{se}=$ standard error. $\mathrm{ci}=$ confidence interval. Outcome variable scaled 1 to $5 . * p<.05, * * p<.01, * * *$

$p<.001$. See appendix for the range, mean and standard deviation of each predictor variable. 
Table 3. Fitted Linear Models of Believing that it is Acceptable to Use Violence to Deal with Disputes

\begin{tabular}{|c|c|c|c|c|c|c|c|c|}
\hline & \multicolumn{2}{|c|}{ Model I } & \multicolumn{2}{|c|}{ Model II } & \multicolumn{2}{|c|}{ Model III } & \multicolumn{2}{|c|}{ Model IV } \\
\hline & $\begin{array}{c}\text { coeff. } \\
\text { (se.) }\end{array}$ & ci. & $\begin{array}{c}\text { coeff. } \\
\text { (se.) }\end{array}$ & ci. & $\begin{array}{c}\text { coeff. } \\
\text { (se.) }\end{array}$ & ci. & $\begin{array}{c}\text { coeff. } \\
\text { (se.) }\end{array}$ & ci. \\
\hline \multicolumn{9}{|c|}{$\begin{array}{l}\text { Work status (referent: full-time, } 30+\text { hours per } \\
\text { week) }\end{array}$} \\
\hline \multirow[t]{2}{*}{ Part-time, 8-29 hours per week } & 0.01 & & 0.02 & & 0.02 & & 0.03 & \\
\hline & $(-0.08)$ & {$[-0.15,0.17]$} & $(-0.08)$ & {$[-0.14,0.18]$} & $(-0.08)$ & {$[-0.14,0.18]$} & $(-0.08)$ & {$[-0.13,0.19]$} \\
\hline \multirow[t]{2}{*}{ Not working } & 0.22 & & $0.25^{*}$ & & 0.23 & & 0.21 & \\
\hline & $(-0.13)$ & {$[-0.03,0.47]$} & $(-0.13)$ & {$[0.00,0.50]$} & $(-0.13)$ & {$[-0.01,0.48]$} & $(-0.13)$ & {$[-0.03,0.46]$} \\
\hline \multirow[t]{2}{*}{ Registered unemployed } & 0.18 & & 0.20 & & 0.21 & & 0.19 & \\
\hline & $(-0.14)$ & {$[-0.09,0.46]$} & $(-0.14)$ & {$[-0.07,0.48]$} & $(-0.14)$ & {$[-0.05,0.48]$} & $(-0.14)$ & {$[-0.07,0.46]$} \\
\hline \multirow{2}{*}{ Unemployed but not registered } & $-0.71 *$ & & $-0.62 *$ & & -0.56 & & -0.53 & \\
\hline & $(-0.30)$ & {$[-1.30,-0.13]$} & $(-0.30)$ & {$[-1.21,-0.04]$} & $(-0.29)$ & {$[-1.13,0.02]$} & $(-0.29)$ & {$[-1.11,0.04]$} \\
\hline \multirow[t]{2}{*}{ Student/full-time education } & -0.07 & & -0.04 & & -0.02 & & -0.02 & \\
\hline & $(-0.07$ & {$[-0.21,0.07]$} & $(-0.07)$ & {$[-0.18,0.10]$} & $(-0.07)$ & {$[-0.16,0.11]$} & $(-0.07)$ & {$[-0.16,0.11]$} \\
\hline \multirow[t]{2}{*}{ 'Other' employment status } & 0.06 & & 0.10 & & 0.03 & & 0.02 & \\
\hline & $(-0.28)$ & {$[-0.49,0.62]$} & $(-0.28)$ & {$[-0.45,0.65]$} & $(-0.28)$ & {$[-0.51,0.57]$} & $(-0.27)$ & {$[-0.52,0.56]$} \\
\hline \multicolumn{9}{|c|}{$\begin{array}{l}\text { Home/residential status (referent: own home } \\
\text { outright) }\end{array}$} \\
\hline \multirow[t]{2}{*}{ Buying on a mortgage } & 0.12 & & 0.11 & & 0.11 & & 0.09 & \\
\hline & $(-0.11)$ & {$[-0.09,0.34]$} & $(-0.11)$ & {$[-0.10,0.33]$} & $(-0.11)$ & {$[-0.10,0.32]$} & $(-0.11)$ & {$[-0.12,0.30]$} \\
\hline \multirow[t]{2}{*}{ Renting from the council } & 0.06 & & 0.06 & & 0.05 & & 0.05 & \\
\hline & $(-0.10)$ & {$[-0.14,0.27]$} & $(-0.10)$ & {$[-0.15,0.26]$} & $(-0.10)$ & {$[-0.15,0.24]$} & $(-0.10)$ & {$[-0.15,0.25]$} \\
\hline \multirow[t]{2}{*}{ Renting from a housing association } & 0.09 & & 0.09 & & 0.13 & & 0.12 & \\
\hline & $(-0.13)$ & {$[-0.17,0.35]$} & $(-0.13)$ & {$[-0.17,0.35]$} & $(-0.13)$ & {$[-0.13,0.38]$} & $(-0.13)$ & {$[-0.13,0.37]$} \\
\hline \multirow[t]{2}{*}{ Renting from a private landlord } & 0.07 & & 0.13 & & 0.15 & & 0.15 & \\
\hline & $\left(-0.10_{-}\right.$ & {$[-0.13,0.28]$} & $(-0.10)$ & {$[-0.07,0.33]$} & $(-0.10)$ & {$[-0.05,0.35]$} & $(-0.10)$ & {$[-0.05,0.34]$} \\
\hline \multirow[t]{2}{*}{ 'Other' home/residential status } & $0.49^{*}$ & & $0.52 *$ & & $0.57 * *$ & & $0.59 * *$ & \\
\hline & $(-0.20)$ & {$[0.09,0.89]$} & $(-0.20)$ & {$[0.12,0.92]$} & $(-0.20)$ & {$[0.18,0.96]$} & $(-0.20)$ & {$[0.19,0.98]$} \\
\hline \multicolumn{9}{|l|}{ Social class (referent: A) } \\
\hline \multirow[t]{2}{*}{$\mathrm{B}$} & -0.23 & & -0.23 & & -0.22 & & -0.02 & \\
\hline & $(-0.52)$ & {$[-1.25,0.79]$} & $(-0.51)$ & {$[-1.23,0.78]$} & $(-0.51)$ & {$[-1.21,0.77]$} & $(-0.51)$ & {$[-1.02,0.97]$} \\
\hline \multirow[t]{2}{*}{$\mathrm{C} 1$} & -0.11 & & -0.08 & & -0.07 & & 0.13 & \\
\hline & $(-0.51)$ & {$[-1.11,0.90]$} & $(-0.51)$ & {$[-1.08,0.92]$} & $(-0.50)$ & {$[-1.06,0.91]$} & $(-0.50)$ & {$[-0.86,1.11]$} \\
\hline \multirow[t]{2}{*}{$\mathrm{C} 2$} & -0.08 & & -0.05 & & -0.03 & & 0.17 & \\
\hline & $(-0.51)$ & {$[-1.09,0.93]$} & $(-0.51)$ & {$[-1.05,0.95]$} & $(-0.50)$ & {$[-1.01,0.96]$} & $(-0.50)$ & {$[-0.82,1.15]$} \\
\hline \multirow[t]{2}{*}{$\mathrm{D}$} & -0.03 & & 0.00 & & 0.00 & & 0.17 & \\
\hline & $(-0.51)$ & {$[-1.04,0.98]$} & $(-0.51)$ & {$[-1.00,1.00]$} & $(-0.50)$ & {$[-0.99,0.98]$} & $(-0.50)$ & {$[-0.81,1.16]$} \\
\hline \multirow[t]{2}{*}{$\mathrm{E}$} & 0.19 & {$[-0.82,1.21]$} & 0.20 & {$[-0.81,1.20]$} & 0.21 & {$[-0.79,1.20]$} & 0.39 & {$[-0.60,1.39]$} \\
\hline & & & 18 & & & & & \\
\hline
\end{tabular}


Age

Stopped by the police (referent: not stopped)

....and received no procedural justice

....and received some procedural justice

....and received strong procedural justice

Trust in police procedural justice

Trust in police effectiveness

Perceived police legitimacy

Fear of crime

Feeling of belonging to Britain

Attitudes towards democracy

(Constant)

$2.31 * * *$ $(-0.54)$

842

0.08

R-squared

0.10
$(-0.50)$

$[-0.03,0.00] \quad(-0.01)$

$[-0.03,0.00]-(-0.01)$

$-0.01$

$-0.03,0.00$

$(-0.01)$

$\begin{array}{cccc}0.20 * & 0.09 & 0.07 & 0.06\end{array}$

$\begin{array}{lllllll}(-0.10) & {[0.00,0.39]} & (-0.10) & {[-0.11,0.29]} & (-0.10) & {[-0.12,0.27]} & (-0.10)\end{array}$

$[-0.05,0.33]$

0.17

$(-0.10)$

$[-0.10,0.29]$

$(-0.10)$

$[-0.11,0.27]$

$(-0.10)$

0.17

$(-0.10) \quad[-0.03,0.34] \quad(-0.09)$

$-0.04 * *$

$(-0.01)$

$-0.02$

$(-0.02)$

$(-0.09)$

$[-0.01,0.36]$

$-0.09)$

0.02

$(-0.02) \quad[-0.03,0.04] \quad(-0.02)$

$-0.01$

$-0.01$

$(-0.02) \quad[-0.04,0.02] \quad(-0.02)$

$[-0.04,0.02]$

$\begin{array}{ccc}- & - \\ 0.09 * * * & {[-0.13,-} & 0.08 * * *\end{array}$

$\left.\begin{array}{lll}(-0.02) & 0.06] & (-0.02)\end{array}\right][-0.12,-0.05]$

$-0.01$

$(-0.01) \quad[-0.03,0.01]$

$-0.02$

$(-0.01) \quad[-0.04,0.01]$

$-0.04 * *$

$-0.01)$
$2.92 * * *$$[-0.07,-0.02]$

$[1.87,3.96]$

Note: coeff $=$ unstandardized coefficient. $\mathrm{se}=$ standard error. $\mathrm{ci}=$ confidence interval. Outcome variable scaled 1 to $5 . * p<.05, * * p<.01, * * *$

$p<.001$. See appendix for the range, mean and standard deviation of each predictor variable. 
Table 4. Fitted Linear Models of Believing that it is Acceptable to Use Violence to Achieve Political Goals

\begin{tabular}{|c|c|c|c|c|c|c|c|c|}
\hline & \multicolumn{2}{|c|}{ Model I } & \multicolumn{2}{|c|}{ Model II } & \multicolumn{2}{|c|}{ Model III } & \multicolumn{2}{|c|}{ Model IV } \\
\hline & $\begin{array}{l}\text { coeff. } \\
\text { (se.) }\end{array}$ & ci. & $\begin{array}{l}\text { coeff. } \\
\text { (se.) }\end{array}$ & ci. & $\begin{array}{l}\text { coeff. } \\
\text { (se.) }\end{array}$ & ci. & $\begin{array}{c}\text { coeff. } \\
\text { (se.) }\end{array}$ & ci. \\
\hline $\begin{array}{l}\text { Work status (referent: full-time, } 30+\text { hours } \\
\text { per week) }\end{array}$ & & & & & & & & \\
\hline Part-time, 8-29 hours per week & $\begin{array}{l}0.26^{*} \\
(0.12)\end{array}$ & {$[0.03,0.48]$} & $\begin{array}{l}0.26 * \\
(0.11)\end{array}$ & {$[0.04,0.49]$} & $\begin{array}{l}0.27 * \\
(0.11)\end{array}$ & {$[0.04,0.49]$} & $\begin{array}{l}0.28 * \\
(0.11)\end{array}$ & {$[0.06,0.49]$} \\
\hline Not working & $\begin{array}{l}0.52 * * \\
(0.18)\end{array}$ & {$[0.17,0.87]$} & $\begin{array}{l}0.50 * * \\
(0.18)\end{array}$ & {$[0.15,0.85]$} & $\begin{array}{l}0.49 * * \\
(0.18)\end{array}$ & {$[0.14,0.83]$} & $\begin{array}{c}0.47 * * \\
(0.17)\end{array}$ & {$[0.13,0.81]$} \\
\hline Registered unemployed & $\begin{array}{l}-0.02 \\
(0.19)\end{array}$ & {$[-0.40,0.36]$} & $\begin{array}{l}-0.03 \\
(0.19)\end{array}$ & {$[-0.41,0.35]$} & $\begin{array}{l}-0.02 \\
(0.19)\end{array}$ & {$[-0.39,0.36]$} & $\begin{array}{l}-0.03 \\
(0.19)\end{array}$ & {$[-0.40,0.33]$} \\
\hline Unemployed but not registered & $\begin{array}{l}-0.43 \\
(0.42)\end{array}$ & {$[-1.25,0.40]$} & $\begin{array}{l}-0.42 \\
(0.42)\end{array}$ & {$[-1.24,0.40]$} & $\begin{array}{l}-0.36 \\
(0.42)\end{array}$ & {$[-1.18,0.46]$} & $\begin{array}{l}-0.28 \\
(0.41)\end{array}$ & {$[-1.08,0.52]$} \\
\hline Student/full-time education & $\begin{array}{c}0.10 \\
(0.10)\end{array}$ & {$[-0.09,0.30]$} & $\begin{array}{c}0.13 \\
(0.10)\end{array}$ & {$[-0.07,0.32]$} & $\begin{array}{c}0.13 \\
(0.10)\end{array}$ & {$[-0.06,0.33]$} & $\begin{array}{c}0.13 \\
(0.10)\end{array}$ & {$[-0.06,0.32]$} \\
\hline 'Other' employment status & $\begin{array}{l}-0.21 \\
(0.40)\end{array}$ & {$[-0.98,0.57]$} & $\begin{array}{l}-0.16 \\
(0.39)\end{array}$ & {$[-0.93,0.61]$} & $\begin{array}{l}-0.22 \\
(0.39)\end{array}$ & {$[-0.99,0.55]$} & $\begin{array}{c}-0.31 \\
(0.38)\end{array}$ & {$[-1.06,0.44]$} \\
\hline $\begin{array}{l}\text { Home/residential status (referent: own } \\
\text { home outright) }\end{array}$ & & & & & & & & \\
\hline Buying on a mortgage & $\begin{array}{c}0.23 \\
(0.15)\end{array}$ & {$[-0.08,0.53]$} & $\begin{array}{c}0.21 \\
(0.15)\end{array}$ & {$[-0.09,0.51]$} & $\begin{array}{c}0.21 \\
(0.15)\end{array}$ & {$[-0.09,0.50]$} & $\begin{array}{c}0.12 \\
(0.15)\end{array}$ & {$[-0.17,0.42]$} \\
\hline Renting from the council & $\begin{array}{c}0.20 \\
(0.14)\end{array}$ & {$[-0.08,0.49]$} & $\begin{array}{c}0.16 \\
(0.14)\end{array}$ & {$[-0.12,0.45]$} & $\begin{array}{c}0.15 \\
(0.14)\end{array}$ & {$[-0.13,0.43]$} & $\begin{array}{c}0.16 \\
(0.14)\end{array}$ & {$[-0.11,0.43]$} \\
\hline Renting from a housing association & $\begin{array}{l}-0.14 \\
(0.19)\end{array}$ & {$[-0.50,0.22]$} & $\begin{array}{l}-0.16 \\
(0.18)\end{array}$ & {$[-0.52,0.20]$} & $\begin{array}{l}-0.13 \\
(0.18)\end{array}$ & {$[-0.49,0.23]$} & $\begin{array}{l}-0.17 \\
(0.18)\end{array}$ & {$[-0.52,0.18]$} \\
\hline Renting from a private landlord & $\begin{array}{l}-0.12 \\
(0.14)\end{array}$ & {$[-0.40,0.17]$} & $\begin{array}{l}-0.10 \\
(0.14)\end{array}$ & {$[-0.38,0.18]$} & $\begin{array}{l}-0.08 \\
(0.14)\end{array}$ & {$[-0.36,0.20]$} & $\begin{array}{l}-0.09 \\
(0.14)\end{array}$ & {$[-0.36,0.19]$} \\
\hline 'Other' home/residential status & $\begin{array}{l}-0.08 \\
(0.29)\end{array}$ & {$[-0.64,0.48]$} & $\begin{array}{l}-0.05 \\
(0.29)\end{array}$ & {$[-0.61,0.51]$} & $\begin{array}{c}0.00 \\
(0.28)\end{array}$ & {$[-0.56,0.56]$} & $\begin{array}{c}0.00 \\
(0.28)\end{array}$ & {$[-0.54,0.55]$} \\
\hline Social class (referent: A) & & & & & & & & \\
\hline $\mathrm{B}$ & $\begin{array}{l}-0.57 \\
(0.72)\end{array}$ & {$[-1.99,0.85]$} & $\begin{array}{l}-0.51 \\
(0.72)\end{array}$ & {$[-1.92,0.90]$} & $\begin{array}{l}-0.51 \\
(0.71)\end{array}$ & {$[-1.91,0.89]$} & $\begin{array}{c}0.01 \\
(0.70)\end{array}$ & {$[-1.37,1.39]$} \\
\hline $\mathrm{C} 1$ & $\begin{array}{l}-0.33 \\
(0.72)\end{array}$ & {$[-1.73,1.08]$} & $\begin{array}{l}-0.27 \\
(0.71)\end{array}$ & {$[-1.67,1.13]$} & $\begin{array}{l}-0.27 \\
(0.71)\end{array}$ & {$[-1.66,1.12]$} & $\begin{array}{c}0.26 \\
(0.70)\end{array}$ & {$[-1.11,1.63]$} \\
\hline $\mathrm{C} 2$ & $\begin{array}{l}-0.18 \\
(0.72)\end{array}$ & {$[-1.59,1.24]$} & $\begin{array}{l}-0.14 \\
(0.71)\end{array}$ & {$[-1.54,1.27]$} & $\begin{array}{c}-0.12 \\
(0.71)\end{array}$ & {$[-1.52,1.27]$} & $\begin{array}{c}0.39 \\
(0.70)\end{array}$ & {$[-0.99,1.76]$} \\
\hline $\mathrm{D}$ & $\begin{array}{l}-0.34 \\
(0.72)\end{array}$ & {$[-1.75,1.08]$} & $\begin{array}{l}-0.28 \\
(0.71)\end{array}$ & {$[1.68,1.12]$} & $\begin{array}{l}-0.29 \\
(0.71)\end{array}$ & {$[-1.68,1.10]$} & $\begin{array}{c}0.17 \\
(0.70)\end{array}$ & {$[-1.19,1.54]$} \\
\hline $\mathrm{E}$ & -0.20 & {$[-1.62,1.22]$} & $\begin{array}{c}-0.15 \\
20\end{array}$ & {$[-1.56,1.26]$} & -0.15 & {$[-1.55,1.25]$} & 0.34 & {$[-1.04,1.71]$} \\
\hline
\end{tabular}




$-0.72)$
-0.01

$[-0.03,0.01]$

Stopped by the police (referent: not stopped)

....and received no procedural justice

$0.40 * *$

(0.13)

0.15

(0.13)

$-0.10$

(0.13)

.

(0.01)

$[-0.03,0.01]$

0.00

....and received some procedural justice

....and received strong procedural justice

Trust in police procedural justice

0.32

$0.32 * \quad 0.30 *$

$\begin{array}{lll}(0.14) & {[0.05,0.59] \quad(0.14)}\end{array}$

$0.13 \quad 0.11$

$[-0.11,0.40]$

(0.13)

$[-0.12,0.38]$

0.11
$(0.13)$

$-0.11-0.10$

$[-0.36,0.16]$

$(0.13)$

$[-0.36,0.15]$

$(0.13)$

$-0.07 * * *$

(0.02) [-0.10, -0.03]

$0.06 * *$

(0.02)

$[0.02,0.10$

$-0.02$

(0.02)

$0.07 * *$

(0.02)

$-0.09 * * *$

$0.29 *$

$[0.03,0.57] \quad(0.13)$

0.18

$[-0.14,0.36]$

(0.13)

$[-0.35,0.16]$

$-0.08$

(0.13)

0.01

$[-0.07,0.03]$

(0.02)

$0.10 * * *$

$[0.03,0.11]$

(0.02)

$-0.08 * *$

(0.02)

$[-0.14,-0.04)$

(0.02)

$0.04 * *$

(0.02)

$-0.06 * * *$

(0.02) [-0.10,-0.03]

$-0.09 * * *$

$[0.03,0.56]$

$[-0.06,0.43]$

$[-0.33,0.17]$

$[-0.04,0.05]$

$[0.05,0.14]$

$[-0.13,-0.03]$

$[0.01,0.07]$

$[-0.13,-0.05]$

Attitudes towards democracy

(Constant)

0.38

(0.75) $[-1.10,1.85]$

0.36

(0.76)

$[-1.13,1.84]$

0.51

$(0.02)$
0.53

(0.74) [-0.92, 1.99]

$\begin{array}{ll}\mathrm{N} & \\ \mathrm{R} \text {-squared } & 0.09\end{array}$

0.11

868
$[-0.96,1.99]$

868

868

0.12

0.16 0.09 $p<.001$. See appendix for the range, mean and standard deviation of each predictor variable. 


\section{REFERENCES}

Anderson, E. (1999). Code of the street: Decency, violence, and the moral life of the inner city. New York, NY: W.W. Norton.

Arendt, H. (2006). On revolution. New York, NY: Penguin Books.

Bittner, E. (1970). The functions of the police in modern society. Washington, DC: National Institute of Mental Health.

Bilz, K. (2007). The puzzle of delegated revenge. Boston University Law Review, 85, 1059-1112.

Black, D. (1983). Crime as social control. American Sociological Review, 48(1), 34-45. doi: $10.2307 / 2095143$

Bottoms, A., \& Tankebe, J. (2012). Beyond procedural justice: A dialogic approach to legitimacy in criminal justice. Journal of Criminal Law and Criminology, 102(1), 119-170.

Bradford, B. (2012). Policing and social identity: Procedural justice, inclusion, and cooperation between police and public. Policing and Society, doi:10.1080/10439463.2012.724068.

Bradford, B., Huq A., Jackson, J., \& Roberts, B. (2013a). What price fairness when security is at stake? Police legitimacy in South Africa. Regulation and Governance. doi:10.1111/rego.12012

Bradford, B., Jackson, J., \& Hough, M. (2013b, forthcoming). Police legitimacy in action: Lessons for theory and practice, in Reisig, M., \& Kane, R. (eds.) The Oxford Handbook of Police and Policing. Oxford: Oxford University Press. Available at SSRN: http://ssrn.com/abstract=2236691

Bradford, B., Jackson, J., \& Stanko, E. A. (2009). Contact and confidence: Revisiting the impact of public encounters with the police. Policing and Society, 19(1), 20-46. doi:10.1080/10439460802457594

Brodeur, J. (2010). The Policing Web. Oxford, UK: Oxford University Press.

Cao, L., Cullen, F., Barton, S., \& Blevins, K. (2002). Willingness to shoot: Public attitudes toward defensive gun use. American Journal of Criminal Justice, 27(1), 85-105. doi:10.1007/BF02898972

Cohen, D. (1996). Law, social policy, and violence: The impact of regional cultures. Journal of Personality and Social Psychology, 70(5), 961-978. doi:10.1037/0022-3514.70.5.961

Duff, R. A. (2012). Relational reasons and the criminal law. Oxford Studies in Philosophy of Law, 2, 2012; Minnesota Legal Studies Research Paper No. 12-30. Available at SSRN: http://ssrn.com/abstract=2103308.

Economist (2011). Anarchy in the UK. The Economist, 400/8746: 14.

European Social Survey (2012). Policing by consent: Understanding the dynamics of police power and legitimacy. ESS Country Specific Topline Results Series Issue 1 (UK). By Jackson, J., Hough, M., Bradford, B., Hohl, K. and Kuha, J. Available at SSRN: URL: http://ssrn.com/abstract=2168702.

Fair, C. C., Malhotra, N., \& Shapiro, J. N. (2010). Islam, militancy, and politics in Pakistan: Insights from a national sample. Terrorism and Political Violence, 22(4), 495-521. doi:10.1080/09546553.2010.492305

Farrall, S., Jackson, J., \& Gray, E. (2009). Social order and the fear of crime in contemporary times. Oxford: Oxford University Press, Clarendon Studies in Criminology.

Ferguson, C. J. (2010). Violent Crime: Clinical and Social Implications. Thousand Oaks, CA: Sage.

FitzGerald, M., Hough, M., Joseph, I., \& Qureshi, T. (2002). Policing for London. Cullompton, UK: Willan Publishing.

Flexon, J., Lurigio, A., \& Greenleaf, R. (2009). Exploring the dimensions of trust in the police among Chicago juveniles. Journal of Criminal Justice, 37, 180-189. doi: http://dx.doi.org/10.1016/j.jcrimjus.2009.02.006.

Gau, J. M., Corsaro, N., Stewart, E. A., \& Brunson, R. K. (2012). Examining macro-level impacts on procedural justice and police legitimacy. Journal of Criminal Justice, 40(4), 333-343. doi:10.1016/j.jcrimjus.2012.05.002

Geerth, H. H., \& Mills, C. W. (1948). From Max Weber: Essays in Sociology. New York, NY: Oxford University Press.

Getzler, J. (2005). Use of force in protecting property. Theoretical Inquiries in Law, 7, 243-278. doi:10.2202/1565-3404.1120 
Gilley, B. (2009). The Right to Rule: How States Win and Lose Legitimacy. New York, NY: Columbia University Press.

Goff, P. A., Epstein, A., \& Reddy, K. F. (2013). Crossing the line of legitimacy: The impact of crossdeputization policy on crime-reporting. Psychology, Public Policy, and Law. doi: 10.1037/a0030123

Gray, E., Jackson, J., \& Farrall, S. (2011). Feelings and functions in the fear of crime: Applying a new approach to victimisation insecurity. British Journal of Criminology, 51(1), 75-94. doi:10.1093/bjc/azq066

Greer, S. (2010). Anti-terrorist laws and the United Kingdom's 'suspect Muslim community'. British Journal of Criminology, 50(6), 1171-1190. doi:10.1093/bjc/azq047

Haas, N. E., Keijser, J. W., de, \& Bruinsma, G. J. N. (2012). Public support for vigilantism: An experimental study. Journal of Experimental Criminology, 8, 387-413. doi: 10.1007/s11292-0129144-1

Haas, N. E., Keijser, J. W., de, \& Bruinsma, G. J. N. (2013). Public support for vigilantism, confidence in police and police responsiveness. Policing and Society. doi: $10.1080 / 10439463.2013 .784298$

Hawdon, J. (2008). Legitimacy, trust, social capital, and policing styles: A theoretical statement. Police Quarterly 11, 182-201. doi: 10.1177/1098611107311852

Hawkins, D. F. (2003). Violent crime: assessing race and ethnic differences. New York, NY: Cambridge University Press.

Hechter, M. (1995). Explaining nationalist violence. Nations and Nationalism, 1, 53-68. doi:10.1111/j.1354-5078.1995.00053.x

Hohl, K., Bradford, B., \& Stanko, E. A. (2010). Influencing trust and confidence in the Metropolitan Police: Results from an experiment testing the effect of leaflet drops on public opinion. British Journal of Criminology, 50(3), 491-513. doi:10.1093/bjc/azq005

Horgan, J. (2005). The psychology of terrorism. London, UK: Routledge.

Hough, M. (1995). Anxiety about crime: Findings from the 1994 British crime survey. Home Office Research Study No. 147. London, UK: Home Office.

Hough, M. (2012). Researching trust in the police and trust in justice: A UK perspective. Policing \& Society, 22(3), 332-345. doi: http://dx.doi.org/10.1080/10439463.2012.671826

Hough, M. (2013). Procedural justice and professional policing in times of austerity. Criminology and Criminal Justice, 13(2), 181-197. doi: 10.1177/1748895812466399

Hough, M., Jackson, J., Bradford, B., Myhill, A., \& Quinton, P. (2010). Procedural justice, trust and institutional legitimacy. Policing: A Journal of Policy and Practice, 4(3), 203-210. doi:10.1093/police/paq027

Hough, M., Jackson, J., \& Bradford, B. (2013a, forthcoming). The governance of criminal justice, legitimacy and trust, in Body-Gendrot, S., Lévy, R., Hough, M. Snacken, S. and Kerezsi, K. (eds.) The Routledge Handbook of European Criminology, Oxon: Routledge. Available at SSRN: http://ssrn.com/abstract=2141811

Hough, M., Jackson, J., \& Bradford, B. (2013b, forthcoming). Legitimacy, trust and compliance: An empirical test of procedural justice theory using the European Social Survey, in Tankebe, J. and Liebling, A. (eds.) Legitimacy and Criminal Justice: An International Exploration, Oxford: Oxford University Press. Available at SSRN: http://ssrn.com/abstract=2234339

Huq, A. Z., Tyler, T. R., \& Schulhofer, S. J. (2011a). Why does the public cooperate with law enforcement? The influence of the purposes and targets of policing. Psychology, Public Policy and the Law, 17(3), 419-450. doi:10.1037/a0023367

Huq, A. Z., Tyler, T. R., \& Schulhofer, S. J. (2011b). Mechanisms for eliciting cooperation in counterterrorism policing: A study of British Muslims. Journal of Empirical Legal Studies, 8(4), 728-761. doi:10.1111/j.1740-1461.2011.01239.x

Jackson, J., \& Bradford, B. (2010). What is trust and confidence in the police? Policing: A Journal of Policy and Practice, 4(3), 241-248. doi:10.1093/police/paq020

Jackson, J., Bradford, B., Hough, M., Kuha, J., Stares, S. R., Widdop, S., Fitzgerald, R., Yordanova, M., \& Galev, T. (2011). Developing European indicators of trust in justice. European Journal of Criminology, 8(4), 267-285. doi:10.1177/1477370811411458 
Jackson, J., Bradford, B., Hough, M., Myhill, A., Quinton, P., \& Tyler, T. R. (2012a). Why do people comply with the law? Legitimacy and the influence of legal institutions. British Journal of Criminology, 52(6), 1051-1071. doi:10.1093/bjc/azs032

Jackson, J., Bradford, B., Stanko, E. A., \& Hohl, K. (2012b). Just authority? Trust in the police in England and Wales. Oxon, UK: Routledge.

Jones, S. (2000). Understanding violent crime. Maidenhead, Kent: Open University Press.

Katz, J. (1988). Seductions of crime: A chilling exploration of the criminal mind from juvenile delinquency to cold-blooded murder. New York, NY: Basic Books.

Krueger, A. B. (2007). What makes a terrorist: Economics and the roots of terrorism. Princeton, NJ: Princeton University Press.

Kruglanski, A., \& Fishman, S. (2006). The psychology of terrorism: Syndrome versus tool perspective. Terrorism and Political Violence, 18(2), 193-215. doi:10.1080/09546550600570119

Kubrin, C. E., \& Weitzer, R. (2003). Retaliatory Homicide: Concentrated Disadvantage and Neighbourhood Culture. Social Problems, 50(2), 157-180. doi:10.1525/sp.2003.50.2.157

Loader, I., \& Mulcahy, A. (2003). Policing and the condition of England: Memory, politics, and culture. New York, NY: Oxford University Press.

Leiken, R. (2012). Europe's angry Muslims: The revolt of the second generation. Oxford, UK: Oxford University Press.

Loeber R., Farrington, D.P., Stouthamer-Loeber, M., \& Van Kammen, W. B. (1998). Antisocial behavior and mental health problems: Explanatory factors in childhood and adolescence. Mahwah, NJ: Lawrence Erlbaum Associates.

Lum, C., Haberfeld, M., Fachner, G., \& Lieberman, C. (2009). Police Activities to Counter Terrorism: What We Know and What We Need to Know. In To Protect and to Service: Policing in an Age of Terrorism, ed. D. Weisburd et al., New York, NY: Springer.

Macpherson, W. (1999). The Stephen Lawrence Inquiry Report. London, UK: The Stationary Office.

Marshall, C. E., \& Webb, V. J. (1994). A portrait of crime victims who fight back. Journal of Interpersonal Violence, 9(1), 45-74. doi: 10.1177/088626094009001004

Mastrofski, S., Reisig, M. D., \& McCluskey, J. D. (2002). Police disrespect toward the public: An encounter-based analysis. Criminology, 40(3), 515-551. doi:10.1111/j.17459125.2002.tb00965.x

Mazerolle, L., Antrobus, E., Bennett, S., \& Tyler, T. R. (2013). Shaping citizen perceptions of police legitimacy: A randomized field trial of procedural justice. Criminology, 51(1), 33-63. doi:10.1111/j.1745-9125.2012.00289.x

Miethe, T. (1995). Fear and withdrawal from urban life. Annals of the American Academy of Political and Social Sciences, 539, 14-27. doi:10.1177/0002716295539001002

Miller, J. (2010). Stop and search in England: A reformed tactic or business as usual? British Journal of Criminology, 50(5), 954-974. doi:10.1093/bjc/azq021

Monahan, J. (2011). The individual risk assessment of terrorism. Psychology, Public Policy, and Law, 18(2), 167-205. doi:10.1037/a0025792

Monahan, J., Steadman, H. J., Robbins, P. C., Appelbaum, P., Banks, S., Grisso, T., Heilbrun, K., Mulvey, E. P., Roth, L., \& Silver, E. (2005). An actuarial model of violence risk assessment for persons with mental disorders. Psychiatric Services, 56(7), 810-815. doi:10.1176/appi.ps.56.7.810

Myhill, A., \& Bradford, B. (2011). Can police enhance public confidence by improving quality of service? Results from two surveys in England and Wales. Policing and Society, 22(4), 397-425. doi:10.1080/10439463.2011.641551

Mythen, G., Walklate, S., \& Khan, F. (2009). I'm a Muslim, but I'm not a terrorist: Victimization, risky identities and the performance of safety. British Journal of Criminology, 49(6), 736-754.

Muro-Ruiz, D. (2002). The logic of violence. Politics, 22(2), 109-117. doi:10.1111/1467-9256.00165

Murphy, K., \& Cherney, A. (2012). Understanding cooperation with police in a diverse society, British Journal of Criminology, 52(6), 181-201. doi:10.1093/bjc/azr065

Murphy, K., Tyler, T. R., \& Curtis, A. (2009). Nurturing regulatory compliance: Is procedural justice effective when people question the legitimacy of the law? Regulation and Governance, 3(1), 126. doi:10.1111/j.1748-5991.2009.01043.x 
Newman, E. (2006). Exploring the 'root causes' of terrorism. Studies in Conflict and Terrorism, 29(8), 749-772. doi:10.1080/10576100600704069

North, D. C., Wallis, J. J., \& Weingast, B.R. (2009). Violence and social orders: A conceptual framework for interpreting recorded human history. Cambridge, MA: Cambridge University Press.

Papachristos, A. V., Meares, T. L., \& Fagan, J. (2012). Why do criminals obey the law? The influence of legitimacy and social networks on active gun offenders, Journal of Criminal Law \& Criminology, 102(2), 397-440.

Pape, R. A. (2005). Dying to win: The strategic logic of suicide terrorism. New York, NY: Random House.

Pape, R. A., \& Feldman, J. K. (2010). Cutting the fuse: The explosion of global suicide terrorism and how to stop it. Chicago, IL: University of Chicago Press.

Pargeter, A. (2008). The new frontiers of jihad: Radical Islam in Europe. Philadelphia, PA: University of Pennsylvania Press.

Phillips, S. (2003). The social structure of vengeance. Criminology, 41(3), 673-708. doi:10.1111/j.1745-9125.2003.tb01001.x

Rengifo, A. F., \& Bolton, A. (2012). Routine activities and fear of crime: Specifying individual-level mechanisms. European Journal of Criminology, 9(2), 99-119. doi:10.1177/1477370811421648

Saucier, G., Akers, L. G., Shen-Miller, S., Kneževié, G., Stankov, L. (2009). Patterns of thinking in militant extremism. Perspectives on Psychological Science, 4(3), 256-271. doi:10.1111/j.17456924.2009.01123.x

Schulhofer, S., Tyler, T. R., \& Huq, A. (2011). American policing at a crossroads: Unsustainable policies and the procedural justice alternative. Journal of Criminal Law and Criminology, 101(2), $335-375$.

Shapiro, J. N., \& Fair, C. C. (2009). Understanding support for Islamist militancy in Pakistan. International Security, 34(3), 79-118.

Skeem, J. L., \& Monahan, J. (2011). Current directions in violence risk assessment. Current Directions in Psychological Science, 20(1), 38-42. doi:10.1177/0963721410397271

Skogan, W. G. (2006). Asymmetry in the impact of encounters with the police. Policing and Society, 16(2), 99-126. doi:10.1080/10439460600662098

Squires, P. (2006). Beyond July 4th? Critical reflections on the self-defence debate from a British perspective. Journal of Law, Economics and Policy, 2(2), 221-264.

Stanko, E. A., Jackson, J., Bradford, B., \& Hohl, K. (2012). A golden thread, a presence amongst uniforms, and a good deal of data: Discourses of confidence in the London Metropolitan Police. Policing and Society, 22(3), 317-331. doi:10.1080/10439463.2012.671825

Stoutland, S. (2001). The multiple dimensions of trust in resident/police relations in Boston. Journal of Research in Crime and Delinquency, 38(3), 226-256. doi:10.1177/0022427801038003002

Stott, C.J., \& Reicher, S.D. (1998). How conflict escalates: The inter-group dynamics of collective football crowd 'violence'. Sociology, 32(2), 353-377. doi:10.1177/0038038598032002007

Sunshine, J., \& Tyler, T. R. (2003). The role of procedural justice and legitimacy in shaping public support for policing. Law and Society Review, 37(3), 555-589. doi:10.1111/1540-5893.3703002

Tankebe, J. (2009). Self-help, policing, and procedural justice: Ghanaian vigilantism and the rule of law. Law and Society Review, 43(2), 245-268. doi:10.1111/j.1540-5893.2009.00372.x

Tankebe, J. (2013). Viewing things differently: The dimensions of public perceptions of police legitimacy. Criminology, 51(1), 103-135. doi:10.1111/j.1745-9125.2012.00291.x

Tilly, C. (2003). The politics of collective violence. New York, NY: Cambridge University Press.

Tyler, T. R. (2006a). Psychological perspectives on legitimacy and legitimation. Annual Review of Psychology, 57, 375-400. doi:10.1146/annurev.psych.57.102904.190038

Tyler, T. R. (2006b). Why people obey the law. Princeton, NJ: Princeton University Press.

Tyler, T. R. (2009). Legitimacy and criminal justice: The benefits of self-regulation. Ohio State Journal of Criminal Law, 7, 307-359.

Tyler, T. R. (2011). Why people cooperate: The role of social motivations. Princeton, NJ: Princeton University Press.

Tyler, T. R., \& Fagan, J. (2008). Why do people cooperate with the police? Ohio State Journal of Criminal Law, 6, 231-275. 
Tyler, T. R., \& Huo, Y. J. (2002). Trust in the Law. New York, NY: Russell-Sage.

Tyler, T. R., Sherman, L., Strang, H., Barnes, G. C., \& Woods, D. (2007). Reintegrative shaming, procedural justice, and recidivism: The engagement of offender's psychological mechanisms in the Canberra rise drinking-and-driving experiment. Law and Society Review, 41(3), 553-586. doi:10.1111/j.1540-5893.2007.00314.x

Tyler, T. R., Schulhofer, S. J., \& Huq, A. Z. (2010). Legitimacy and deterrence effects in counterterrorism policing: A study of Muslim Americans. Law and Society Review, 44(2), 365-401. doi:10.1111/j.1540-5893.2010.00405.x

Tyler, T. R., \& Jackson, J. (2013, forthcoming). Future challenges in the study of legitimacy and criminal justice, in Tankebe, J. and Liebling, A. (eds.) Legitimacy and Criminal Justice: An International Exploration, Oxford: Oxford University Press. Available at SSRN: http://ssrn.com/abstract=2141322 or http://dx.doi.org/10.2139/ssrn.2141322

Ziegenhagan, E. A., \& Brosnan D. (1991). Citizen orientations toward state and non-state policing. Law \& Policy, 13(3), 245-257. doi:10.1111/j.1467-9930.1991.tb00069.x 


\section{APPENDIX}

\section{Outcome variables}

Attitudes towards the use of violence as social control

The question stem for these items are as follows: 'Some people think it is right to use violence to try to solve problems or issues they face, while others think the use of violence is always wrong. Using this card, can you tell me whether you think it would be right or wrong for someone like you to use violence in the following situations....'

Attitudes towards the use of violence to protect oneself

\begin{tabular}{lcc}
\hline Wording & Mean & SD \\
\hline To protect themselves from attack in the street & 3.6 & 1.2 \\
To protect themselves from an intruder in the house & 3.9 & 1.1 \\
\hline
\end{tabular}

Response alternatives: (1) always wrong to (5) always right.

Note: an index was created by taking the mean of the two items: $n=972$, mean=3.8 and standard deviation=1.1.

Attitudes towards the use of violence to take revenge and resolve disputes

\begin{tabular}{lcc}
\hline Wording & Mean & SD \\
\hline To take revenge against someone & 2.1 & 0.8 \\
To resolve a dispute with neighbourhoods & 2.0 & 0.9 \\
\hline
\end{tabular}

Response alternatives: (1) always wrong to (5) always right.

Note: an index was created by taking the mean of the two items: $n=975$, mean $=2.0$ and standard deviation $=0.7$.

Attitudes towards the use of violence to achieve political goals

Question stem: 'I' $d$ like to ask you about some of the things people do to protest against things they feel are very unfair or unjust. Using the same card, please tell me how right or wrong you think each of the following is...'

\begin{tabular}{lccc}
\hline Wording & Mean & SD & $\begin{array}{c}\text { Latent trait } \\
\text { loading }\end{array}$ \\
\hline Use violence to protest against things they think are unfair & 1.9 & 0.9 & 1.86 \\
Writing and distributing leaflets that encourage violence & 1.7 & 0.8 & 3.51 \\
Using violence to protest against effects of globalisation & 1.7 & 0.8 & 3.60 \\
Using violence in the name of religion to protest & 1.6 & 0.8 & 3.90 \\
\hline
\end{tabular}

Response alternatives: (1) always wrong to (5) always right.

Note: an index was created by saving the trait scores from an ordinal latent trait model (using full information maximum likelihood to draw upon all relevant information): $n=1,002$, mean $=0.0$ and standard deviation=1.0. Please contact the first author for item characteristic curves from the latent trait analysis.

\section{Predictor variables}

\section{Police legitimacy}

The questions for the first two items are as follows: 'People have different opinions about how important it is to obey police officers, judges and the law. The following questions are concerned with your own feelings about obeying the law. Please tell me to what extent you agree or disagree with each of these statements.'

Question stem to third and fourth measures: 'To what extent do you agree or disagree that when you deal with the police in London...?'

\begin{tabular}{lccc}
\hline Wording & Mean & SD & $\begin{array}{c}\text { Latent trait } \\
\text { loading }\end{array}$ \\
\hline
\end{tabular}




\begin{tabular}{llcc}
\hline $\begin{array}{l}\text { You should accept police decisions if it is the proper and } \\
\text { right thing to do }\end{array}$ & 3.1 & 0.7 & 2.57 \\
$\begin{array}{l}\text { You should obey police directives if you consider their } \\
\text { actions lawful }\end{array}$ & 3.3 & 0.6 & 2.37 \\
$\begin{array}{l}\text { Police usually act in ways that are consistent with my ideas } \\
\text { of what is right and wrong }\end{array}$ & 2.8 & 0.7 & 1.91 \\
$\begin{array}{l}\text { Police in my neighbourhood always behave according to } \\
\text { the law }\end{array}$ & 3.0 & 0.7 & 1.79 \\
\hline
\end{tabular}

Response alternatives: (1) strongly disagree to (4) strongly agree.

Note: an index was created by saving the trait scores from an ordinal latent trait model (using full information maximum likelihood to draw upon all relevant information), rescaling so that the index went from 0 to $10: n=1,013$, mean=6.0 and standard deviation=1.9. Please contact the first author for item characteristic curves from the latent trait analysis.

\section{Trust in police procedural justice}

Respondents were asked about their assumptions or beliefs about police treatment and decisionmaking. Question stem: 'To what extent do you agree or disagree that when you deal with the police in London...?'

\begin{tabular}{lccc}
\hline Wording & Mean & SD & $\begin{array}{c}\text { Latent trait } \\
\text { loading }\end{array}$ \\
\hline $\begin{array}{l}\text { The police use rules and procedures that are fair to } \\
\text { everyone }\end{array}$ & 2.9 & 0.7 & 2.54 \\
$\begin{array}{l}\text { The police clearly explain reasons for their actions } \\
\begin{array}{l}\text { The police provide opportunity for unfair decisions to be } \\
\text { corrected }\end{array}\end{array}$ & 2.9 & 0.7 & 2.94 \\
$\begin{array}{l}\text { The police make decisions based on fact not personal } \\
\text { opinions }\end{array}$ & 2.9 & 0.7 & 3.32 \\
\hline
\end{tabular}

Response alternatives: (1) strongly disagree to (4) strongly agree.

Note: an index was created by saving the trait scores from an ordinal latent trait model (using full information maximum likelihood to draw upon all relevant information), rescaling so that the index went from 0 to 10: $n=999$, mean=5.7 and standard deviation=2.1. Please contact the first author for item characteristic curves from the latent trait analysis.

\section{Trust in police effectiveness}

Respondents were asked about the effectiveness of the police in performing a number of different roles.

\begin{tabular}{lccc}
\hline Wording & Mean & SD & $\begin{array}{c}\text { Latent trait } \\
\text { loading }\end{array}$ \\
\hline $\begin{array}{l}\text { How well do you think the Metropolitan police tackles drug } \\
\text { dealing and drug use? }\end{array}$ & 4.7 & 1.4 & 2.17 \\
$\begin{array}{l}\text { How well do you think the Metropolitan police tackles gun } \\
\text { crime? }\end{array}$ & 5.0 & 1.3 & 3.06 \\
$\begin{array}{l}\text { How well do you think the Metropolitan police supports } \\
\text { victims and witnesses? }\end{array}$ & 5.2 & 1.3 & 2.78 \\
$\begin{array}{l}\text { How well do you think the Metropolitan police tackles } \\
\text { dangerous driving? }\end{array}$ & 5.2 & 1.2 & 2.27 \\
$\begin{array}{l}\text { How well do you think the Metropolitan police responds to } \\
\text { emergencies promptly? }\end{array}$ & 5.2 & 1.3 & 2.14 \\
$\begin{array}{l}\text { How well do you think the Metropolitan police prevents } \\
\text { terrorism? }\end{array}$ & 5.5 & 1.2 & 1.91 \\
How well do you think they police major events in London? & 5.8 & 1.1 & 1.73 \\
\hline Response
\end{tabular}

Response alternatives: (1) not at all well to (7) very well.

Note: an index was created by saving the trait scores from an ordinal latent trait model (using full information maximum likelihood to draw upon all relevant information), rescaling so that the index 
went from 0 to $10: n=1,010$, mean=5.8 and standard deviation=1.7. Please contact the first author for item characteristic curves from the latent trait analysis.

\section{Contact with the police}

Respondents were asked whether they had been stopped by the police in the past 12 months. If they said yes, they were asked whether they were given a reason for why they had been stopped, whether they had been told what would happen next; whether they had been treated with respect; and whether the police were justified in stopping them. The response alternatives were: 'Yes, fully', 'Yes, to some extent', Not really', and 'Not at all'. A mean value of these items was taken, where 'not at all' equals 0 , 'not really' equals 1 , 'yes, to some extent' equals 2 , and 'yes, fully' equals 3 . No procedural justice was defined as an average between 0 and 1.5, some procedural justice was defined as an average between 1.6 and 2, and procedural justice was defined as an average between 2.1 and 3. Respondents were also asked if they had been searched and/or arrested by the police in the past 12 months (this could be a separate event to having been stopped), and whether or not they had been received procedural justice. The same classification procedure was implemented as above. Finally, a series of dummy variables were created, indicating whether an individual had experienced any of the three types of contact (combining being stopped with being searched and/or arrested). Below are the relevant frequencies.

\begin{tabular}{lcc}
\hline & $\mathrm{n}$ & $\%$ \\
\hline No contact & 784 & 77.1 \\
Contact, received no procedural justice & 76 & 7.5 \\
Contact, received some procedural justice & 80 & 7.9 \\
Contact, received procedural justice & 77 & 7.6 \\
Total & 1,017 & 100 \\
\hline
\end{tabular}

Attitudes towards democracy

Respondents were asked two Likert-style questions.

\begin{tabular}{lcc}
\hline Wording & Mean & SD \\
\hline $\begin{array}{l}\text { Democracy may have many problems, but it is better than any } \\
\text { other system }\end{array}$ & 4.1 & 0.8 \\
$\begin{array}{l}\text { Having a democratic system is a good way of governing this } \\
\text { country }\end{array}$ & 4.2 & 0.8 \\
\hline
\end{tabular}

Response alternatives: (1) strongly disagree to (5) strongly agree

Note: an index was created taking the mean of the two items. The index was rescaled so that it went from 0 to $10: \mathrm{n}=975$, mean $=7.9$ and standard deviation $=1.8$.

\section{Belonging to Britain}

Respondents were asked one question.

\begin{tabular}{lcc}
\hline Wording & Mean & SD \\
\hline How important is your national identity to your sense of who & 4.0 & 0.8
\end{tabular}

you are?

Response alternatives: (1) not at all important to (6) very important. The variable was rescaled so that it went from 0 to 10: $\mathrm{n}=998$, mean=7.5 and standard deviation=2.1.

\section{Fear of crime}

Standard intensity questions of fear of falling victim of crime were used (see Farrall et al., 2009).

Question stem: 'Now I would like to ask you about how much you worry about specific crimes. How worried are you about ...?

\begin{tabular}{lccc}
\hline Wording & Mean & SD & $\begin{array}{c}\text { Latent trait } \\
\text { loading }\end{array}$ \\
\hline ...having your home broken into and something stolen & 2.1 & 0.9 & 1.91 \\
...being mugged or robbed & 2.1 & 0.8 & 2.72 \\
...being physically attacked by strangers & 1.9 & 0.8 & 3.33
\end{tabular}


...being insulted or pestered by anybody while in the street

Response alternatives: (1) not at all worried to (4) very worried

Note: an index was created by saving the trait scores from an ordinal latent trait model (using full information maximum likelihood to draw upon all relevant information), rescaling so that the index went from 0 to 10: $n=1,017$, mean=3.9 and standard deviation=2.3. Please contact the first author for item characteristic curves from the latent trait analysis. 


\footnotetext{
i A recent study by Haas et al. (2013) similarly linked 'diffuse support' for the police (specifically, generalized trust and confidence in the police) with support for vigilantism in the Netherlands (see also Haas et al., 2012).

ii Boroughs are further subdivided into 624 wards.

iii Social class A refers to higher managerial, administrative and professional occupations. Social class B refers to intermediate managerial, administrative and professional occupations. Social class C1 refers to supervisory or clerical and junior managerial, administrative and professional occupations. Social class C2 refers to skilled manual occupations. Social class D refers to semi-skilled and unskilled manual occupations. Finally, social class E refers to casual labourers, state pensioners, and the unemployed.

iv It is important to measure people's encounters with the police (and specifically whether they were treated fairly by officers) as well as people's more general beliefs about the procedural fairness of police action.

v It is important to differentiate between trust and legitimacy. In the words of Hawdon (2008: 186): "The role is legitimate; the individual is trusted." Measures of trust might focus on the intentions and capabilities of individual officers - whether the officers can be trusted to fulfil specific institutional functions, like being effective, fair, dependable and have appropriate priorities (see, e.g., Stoutland, 2001; Flexon et al., 2009). Measures of legitimacy might focus on the authority that the institution (the role) confers onto individual officers and, conversely, the moral validity that actions of individual officers confers back to the institution and role. For discussion on the meaning and measurement of legitimacy, see: Jackson et al., (2011); Bottoms \& Tankebe (2012); Tankebe (2013); and Tyler \& Jackson (2013).

${ }^{\mathrm{vi}}$ Papachristos et al. (2012) measured perceived legitimacy using the following four measures: 'I feel that I should accept the decisions made by legal authorities', 'People should obey the law even if it goes against what they think is right', 'The law represents the values of people in power rather than the values of people like me [reverse coded]', and 'People in power use the law to try and control people like me [reverse coded]'. These measures are similar to those used in our study (see the appendix), in that the first two indicators focus on felt obligation to obey and the second two indicators focus on the moral validity of legal authority.

vii While we use standard British intensity measures of fear of crime (Hough, 1995), we acknowledge that there are complexities underlying the meaning and measurement of fear of crime that we cannot address in the context of the current study (see, for example, Gray et al., 2011).

${ }_{\text {viii }}$ Although see Bradford et al. (2009) and Jackson et al. (2012b).

ix The belief that the police are effective nevertheless appears in narrow circumstances to be associated with increased acceptance of private violence for social change. This correlation appears only when controls are added for procedural justice and police legitimacy. There are two potential explanations for this finding. First, a perception of police efficacy may conduce to the idea that some problems can be solved through force. We find this account unconvincing. There is no reason why the same perception would not also influence attitudes toward private violence for social control. Second, and more likely, it may be that within the young minority population studied here, belief in police effectiveness is correlated with antiauthoritarian attitudes. That is, those who object to extensive use of state authority tend to view state authority as efficacious, able to exert force on citizens, also tend to believe that it is permissible to use violence against the state. Similar dynamics might be posited in authoritarian regimes, such as the former Soviet bloc, where belief in the efficacy of the police to enact repression might produce greater willingness to resist the state.
} 